\title{
Retail Signage During the COVID-19 Pandemic
}

\section{Joanne E. McNeish}

Associate Professor

School of Business Management

Ryerson University

jmcneish@ryerson.ca

\section{INTRODUCTION}

If someone had proposed the need to introduce and reinforce social distancing on the world, over a very short time period, most people would have thought it impossible (Furman University 2020). Yet in the first quarter of 2020, and as each country in the world encountered COVID 19, social distancing became a necessary social norm and one of the only defenses to this new highly transmittable respiratory virus. To support the government's communication and regulatory efforts, retail store signs became important in creating awareness of, educating about, and reinforcing social distancing behavior. This paper first describes the signs used by retailers in March and April 2020 and then speculates on their meaning beyond their conventional role in geographic wayfinding.

Social distancing is a term used in public health to describe the necessary actions taken to avoid infectious contact. Given the magnitude of this pandemic and the general lack of public awareness of the term, the Public Health Agency of Canada (2020) began explaining social distancing and the actions that people needed to take in early March, using press briefings, public service announcements, information posted to their website and on social media. Social distancing behaviors initially included avoiding crowded places and non-essential gatherings, avoiding greetings that involve touching, and limiting contact with high risk populations (Public Health Agency of Canada 2020). Over time, formal stay at home, mask, and group size orders were enacted and governments impressed upon their populations to maintain two-meter / six-foot distance from non-family members and consistent handwashing practices.

Rapidly breaking habits of human touch and close physical distance required clear and consistent communication by health and government officials.

\section{Abstract /}

Early in 2020 the COVID-19 pandemic began to impact countries across the world. Within weeks, people's normal social behavior had to be changed in order to stop the spread of the disease. In Canada, where this study takes place, governments and public health departments were the primary and trusted information sources. Photographs of retail signs were taken by the author in one neighborhood in a major Canadian city in March and April. Along with descriptive information, the author speculates on the meaning conveyed by the printer-paper signs, beyond their traditional role of supporting wayfinding. Paper's relative fragility may have simultaneously reflected the uncertainty that people felt in the early days of the pandemic, while its familiar and timeless presence may have provided a sense of emotional security and direction. Marking a return to "business as usual", stores replaced many, but not all of the informal signs with professionally produced and branded signs suggesting that the early "blind panic" had been replaced by a form of "steady state". One could say that retailers demonstrated corporate social responsibility through their efforts in creating and posting the signs to create awareness of, educate, and reinforce the new and changing social distancing behaviors.

\section{Keywords /}

retail; social distancing; covid-19 pandemic; paper signs 
Social distancing was at first suggested and then recommended; non-urgent voluntary compliance was replaced with urgent and stern warnings, and finally with regulations and financial penalties for non-compliance (Benzie 2020; DeClerq 2020; Tumilty 2020). As the situation became dire, and in order to keep as many people as possible at home, governments closed down non-essential services. Closing down meant that employees had to be sent home to continue to work, or if the work could not be performed at home, to be laid off until the pandemic subsided. The list of non-essential services included many types of retail stores but excluded, for example, grocery stores, pharmacies, and banks (Ontario Government 2020). Table 1, as shown in the Appendix, traces the timing of the emergency orders and the businesses deemed essential, or not.

Retailers often play a role in supporting the communication of socially desirable changes advocated by government (Pollay 2007). Two recent Canadian examples, reducing obesity levels and discouraging tobacco smoking are discussed here. In 2017, Ontario restaurants with 20 or more locations were required to include the caloric count of food and drink on menus and in-store signage (Moghimi and Wiktorowicz 2019). Studies have found that consumers find this type of messaging useful in making food choices that reduce fat and sugar intake, or portion sizes (Adam and Jensen 2016). In 2018, the Ontario government reduced the visibility of tobacco and vaping products and limited in-store signs to unbranded information in order to decrease awareness of the products, particularly among teenagers. Retail stores received rules for the size, shape, color, and messages of in-store signs and displays (Ottawa Public Health 2020). These regulations were introduced after extensive and lengthy consultations with retailers and their associations, and lengthy timelines allowed for retailers to prepare for, and comply with the regulations gradually. One could characterize the behavior of retailers in supporting the socially desirable changes as evidence of corporate social responsibility, where "business decision making [is] linked to ethical values, compliance with legal requirements, and respect for people, communities, and the environment around the world" (Aaronson 2003, 310).
COVID-19, on the other hand, was an unprecedented event and consultations were simply not possible given the severity of the situation. Government and retailers had very little warning of the events that would overtake them and even less time to react. As a result, retailers received the same general information at almost the same time as their customers and without much time for discussion or training, retailers had to figure how the information applied to their physical operations, employees, and customers.

Retailers make extensive use of professionally produced physical and/or digital signs outside, and inside their stores. These signs are used to convey information such as: the name of the company, opening and closing hours, pricing and sales, coupons and promotions, product, and service-related information (Carpenter and Moore 2006; Vizcaíno 2018). Typically, in-store signs serve the purpose of providing information and acting as prompts. Lehman and Geller (2004) discuss the importance of prompts in reminding people of how to behave. Using specific colors and fonts, signs also support the retailer's brand image (Huddleston et al. 2015).

Under normal operating circumstances, one would rarely see a business using signs printed on $8.5 \times 11$, run of the mill printer paper. Yet, during the early stages of the pandemic, businesses of all sizes used paper signs extensively to convey information about the required social distancing behaviors. One wonders why, in a country such as Canada where literacy levels are high and technology and digital communication is widely available, that retailers used paper so extensively to communicate with their customers.

This paper explores the way in which signs were used in the early months of the COVID-19 pandemic in one area of Toronto, Canada. It documents the transition from paper signs to professionally produced and branded signs as a way to understand the real-time development of retailers' communication efforts.

\section{METHOD}

This is an unusual study. First, the COVID-19 virus rapidly spread across the globe and there appears to be no natural immunity. There is (at the time 
of writing) no cure or vaccine. Second, the rapidly unfolding events, meant that there was no time to conduct a research study that involved customer or retailer interviews.

Phenomenological research makes use of the observer's lived experience as the starting point for understanding an experience (Neubauer, Witkop, and Varpio 2019). The author is both the researcher and the observer. In the same way as other customers, the author used informal signs for their functional wayfinding purpose (what to do, where to stand and move, and how to behave) (Mollerup 2005). At the same, the author felt compelled to photograph them in order to preserve them. Across the world, journalists and other people also photographed retailers' signs online (Carlberg 2020; Fortin 2020; Mercer 2020; Toh 2020).

In this study, "informal sign" is used to describe the signs with messages printed or handwritten on standard printer paper. To create the informal signs, businesses used ordinary white printer paper, probably $20 \mathrm{lb}$ bond, and produced signs on local office printers or photocopiers. A few were printed or written on card stock or cloth material (Quill n.d.). "Professional sign" refers to signs that were created and produced by a printing company and that use the brand's colors, fonts, logos, or images.

The data collected for this study was restricted to a small geographic area of one large city because of the social distancing requirements imposed by the Canadian federal, provincial, and municipal governments. In March and April, the Emergency Management and Civil Protection Act restricted residents to their homes only leaving them for groceries and essential goods such as prescriptions, and to exercise or walk pets.

Operating within those restrictions, the author took photographs of exterior and interior retail store signs within a two and half kilometer radius of their home, in Toronto's 16th electoral ward. Figure 1 is a simplified map of the area photographed, showing the open-air shopping malls (green circles) plus single location or multi-location businesses (marked as thicker red lines and white arrows).

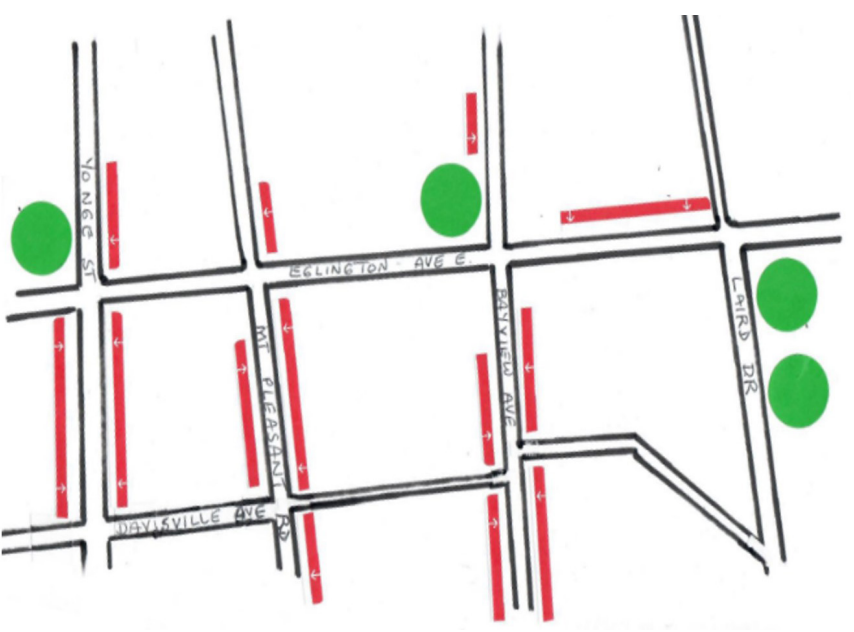

Figure 1 / Map of the photographed area

This area is a mix of residential types, including single-family and townhomes and low and high-rise apartment buildings, and commercial businesses. The residents of the two areas are comparatively affluent, with above average rates of income and education. The retail stores and businesses range in size; some are small, single location businesses while others are part of large companies that have multiple locations. Other researchers interested in comparing the data in this study to other areas, can find detailed census data for Ward 16 on the City of Toronto's website.

Using an iPhone, the author photographed the signs linked to COVID-19 used by retailers between March 13 and April 27, 2020. Using photographs as a way to understand human and organizational behavior is appropriate under many conditions, and photographs may be especially useful in a fast-moving and unprecedented situation like this one to capture the rapidly changing environment. Photographs provide "clues about the embodied nature of organizational practices as well as the latent emotional processes and reactions" (Ray and Smith 2012, 295).

Approximately 500 photographs were taken, randomly at first, and as the situation continued a more systematic sampling approach was used, all the while still social distancing. The stores that the author could enter, grocery stores and pharmacies, were visited once a week. Each of the major streets in Ward 16 was visited every three to four days. The outside doors and windows of the stores along Bayview Avenue, Mt. 
Pleasant Road, Yonge Street, and Laird Avenue were inspected to identify changes over time. At least one restaurant was visited daily.

In this study, the term "retailer" is used to describe to any business with a physical location. Retailers under this definition include grocery stores, pharmacies, clothing stores, hardware stores, office goods, restaurants, physicians, dentists, lawyers, hair and nail salons, spas, pet stores and grooming services, veterinarians, and real estate agents.

\section{FINDINGS}

This section begins with a timeline of key events, regulations, and legislation from January to April 2020. This is followed by a description of the signs used by small single location retailers and large multi-location retailers.

The timeline presented in Table 2 (in Appendix) provides background information to the study. Of particular note is the speed at which the retailers and citizens adjusted to new and continuously changing conditions. The first presumptive case of a Canadian contracting COVID-19 was recorded in January 2020, however, the first event visibly affecting retailers and their customers did not occur until March 4. This is when a ban on reusable cups and containers was introduced. On March 6 the World Health Organization declared COVID-19 a pandemic and just over a week later the Ontario government evoked the Emergency Management and Civil Protection Act (Ontario 2020) that mandated new behavior. From this point onwards, the situation escalated rapidly for a month and a half, with frequent behavioral changes required from both consumers and retailers. On April 27, with curve of COVID-19 virus cases beginning to flatten, the Ontario government announced a three-step plan to reopen the province's businesses. They cautioned that the reopening would continue only if key statistics remain positive (the number of deaths remains low and declining and the time between doubling of identified cases continues to lengthen). They also declared that social distancing would continue for an unknown time-period.

\section{General Observations}

Throughout March, most informal signs were printed on $8.5 \mathrm{x} 11$ white printer paper. The fonts used were mostly black, on-serif, and a mix of upper- and lower-case letters, with italicization and color used infrequently. Bold was used to emphasize key points. Exterior signs were placed at various locations and heights on doors and windows. Among the locations that remained open to customers, signs could be found in the interior front entrances and throughout the store (on walls and poles, stands, shelves, and on the floor). Regular scotch tape or duct tape was used to affix the signs to walls, no matter the size of the retailer. Through March and April, digital signs were used only to present product and pricing information. They were not observed to display any COVID-related information. 
With each new behavior imposed by government, new signs were required. These were often posted alongside existing signs. By early April, stores that remained open to customers had started to replace many, but not all, of the informal signs with professional ones. The rapidly changing information, which required the original signs to be quickly and frequently changed, gave way to information that was required for the long term, such as social distancing. Thus, the cost and effort required to create professional signs could be justified by retailers.

\section{Single Location Retailers}

Single location retailers who were required by law and/or chose to close, took a more personal approach to announce their operating status. Almost all of these informal signs were typed using in black, non-serif, small font in upperand lower-case letters. Those that were handwritten, used mainly black or blue ink pens, while a few others used colored markers.

Some signs had concise messages, while others filled up a page. Most presented the personal reaction of the retailer to the pandemic. "We are all in this together" was a major theme along with a focus on the customers and community's well-being. Some of the informal signs reflected the thinking at the time, which was that this would be a short-term (two-week) closure. One might wonder if that perception (that the situation would be short term) was the reason why most small businesses that closed, did not provide alternative methods of contact such as email, phone number, social media, or website. Almost none of the businesses who closed under the first order on March 24 changed the information on their signs over the period of this study.

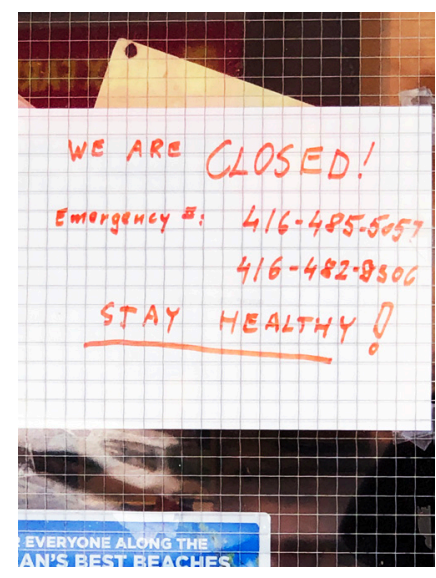

Figure 2

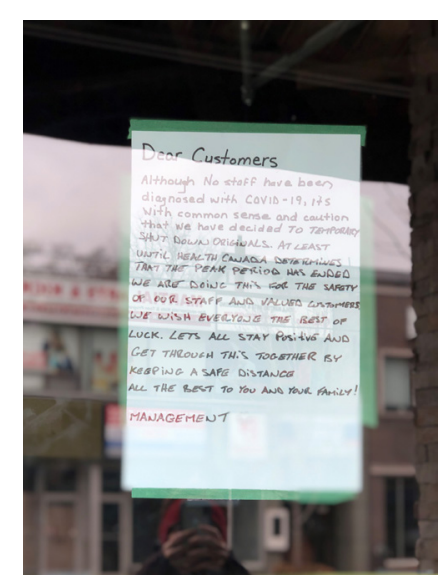

Figure 3

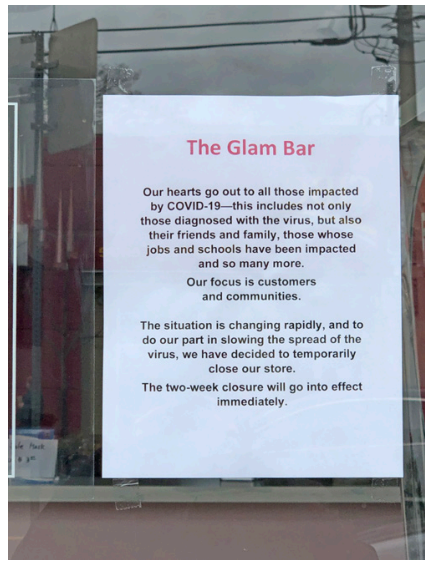

Figure 4

\section{Large Multi-Location Retailers}

In early March there was little understanding among most retailers (or almost anyone else) that the situation would escalate, with the requirement for social distancing to continue for months. The first sign of COVID-19's impact came to customers through informal signs at coffee shops. Tim Hortons (Figure 6), for example, indicated that the restaurant would temporarily stop filling 
customers' reusable cups. As is typical of most early signs, the information was on $8.5 \times 11$ printer paper using black, sans-serif font. Unlike many of the signs posted in early March, the restaurant used the brand's logo as a signature.

Note the ripped and slightly crumpled features of the sign after just a few days of use. Over the study period, the sign was never replaced, becoming increasingly worn and served as an artifact that communicated the initial changes in behavior necessary to protect guests (customers) and team members (customer facing-employees) from COVID-19 exposure. Other retailers also stopped the use of customers' recyclable containers (e.g. bulk bin) but not all put up signs, rather leaving it up to the employees to inform customers.
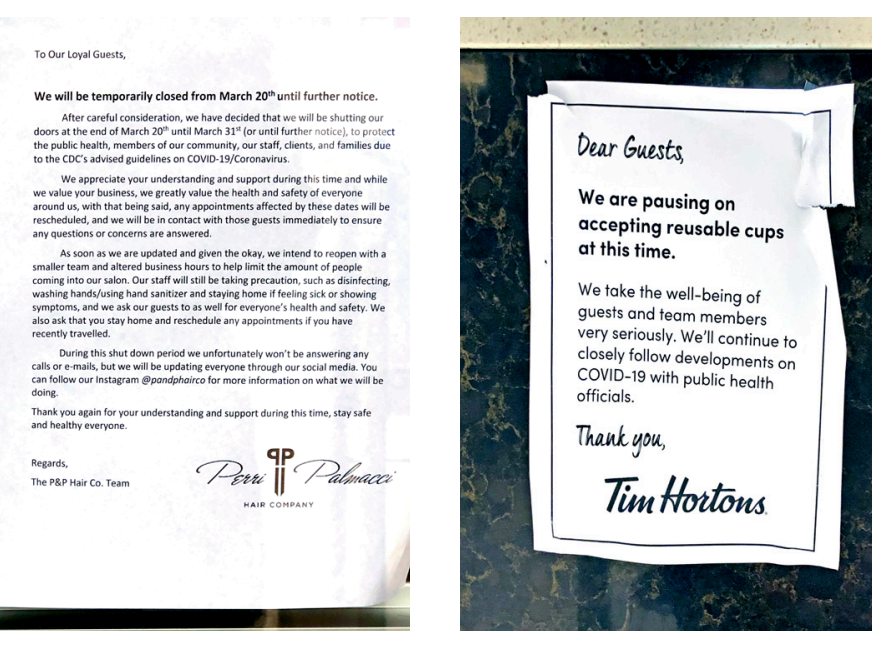

Figures 5 and 6

On March 13 the Ontario government closed schools, universities, and colleges and encouraged citizens to prepare for a nation-wide lockdown (Beck 2020). Heeding this information and anticipating being at home for at least 14 days, people started to panic buy staple goods (Stern 2020). Store shelves and bins went bare, as toilet paper, produce with longer shelf lives, cleaning materials, bottled water, and baking supplies were rapidly sold out. No in-store signs indicated why the shelves are empty. In a city where product stockouts are unusual due to Canada's robust supply chain, grocery stores were overwhelmed by the sudden and unanticipated demand for certain products.
By March 20, grocery stores put up informal signs telling customers about out of stock items, and to manage the supply of scarce items. Signs emerged that indicated how much of limited products could be purchased by each customer. One of the messages
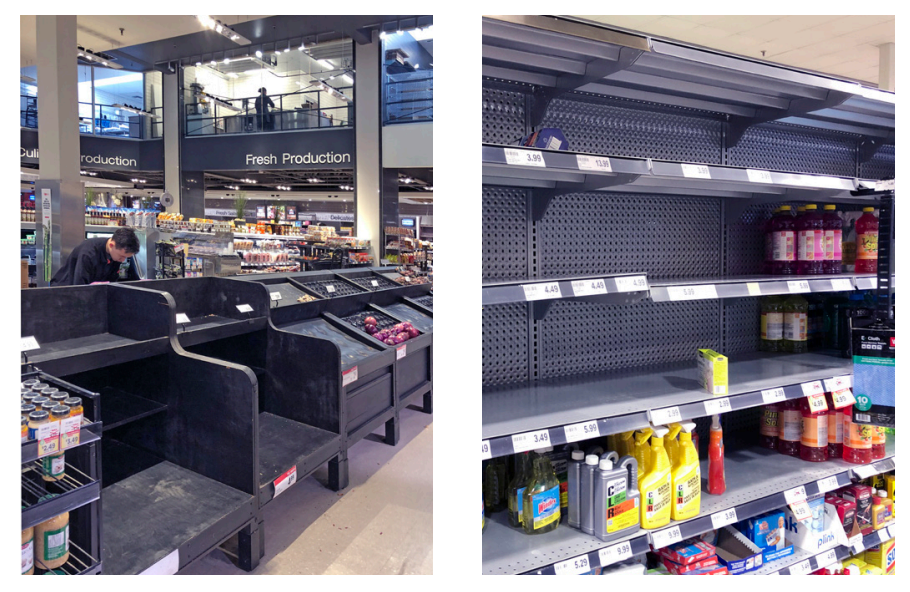

Figures 7 and 8

reinforced sharing with others: "In order to respect and serve all our customers" and the text was bolded and capitalized in a sans-serif font (Figure 9). A space for the number of items that could be purchased was left blank, indicating the likelihood of continued supply-chain disruption. The number of items could be easily written in by hand as the situation unfolded. Note the specific signs for toilet paper (Figure 10): "Attention Customers. There is a 2-unit limit on toilet paper. Thank you for your cooperation." The salutation is starred, and the message is both bolded and capitalized.
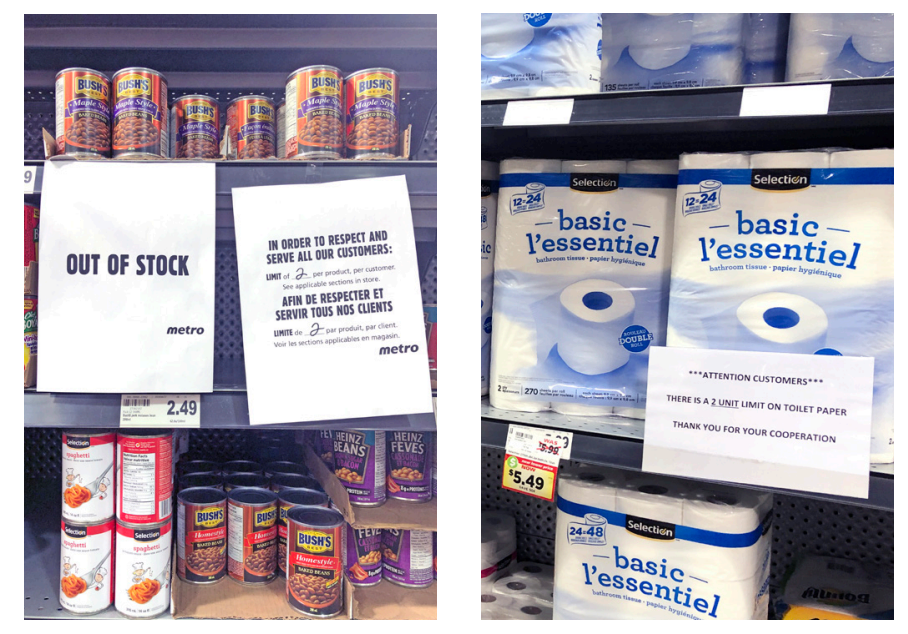

Figures 9 and 10 
Most retailers have multiple customer touchpoints including entering the store, moving around the aisles of the store, and checking out. As the situation progressed, stores had to bring changes to the customer's attention before they even entered the store. One sign indicates the change in reusable bags usage. Note that early in March customers could still bring and use their own bags in stores, however check-out employees were no longer allowed to bag them. Plastic bags were offered for purchase, as is typical in Canada. As the situation progressed, informal signs were attached to check-out stations to indicate newly required social distancing behavior. The use of regular tape to attach the signs was prevalent. Some of the signs had instructions to indicate where employees should place it, whereas others did not. Different messaging was used with some signs reading as instructions and in a neutral tone, "Please follow these steps at Checkout to support social distancing" while another sign communicated a more forceful message: "...guidelines to support the importance of social distancing." The signs indicated that reusable bags were no longer welcome in stores. Now, plastic bags would be offered to customers, without charge, and check-out employees would bag all groceries. The reason for this change was to reduce congestion at the end of the check-out station created by self-bagging and to minimize contact between customers.

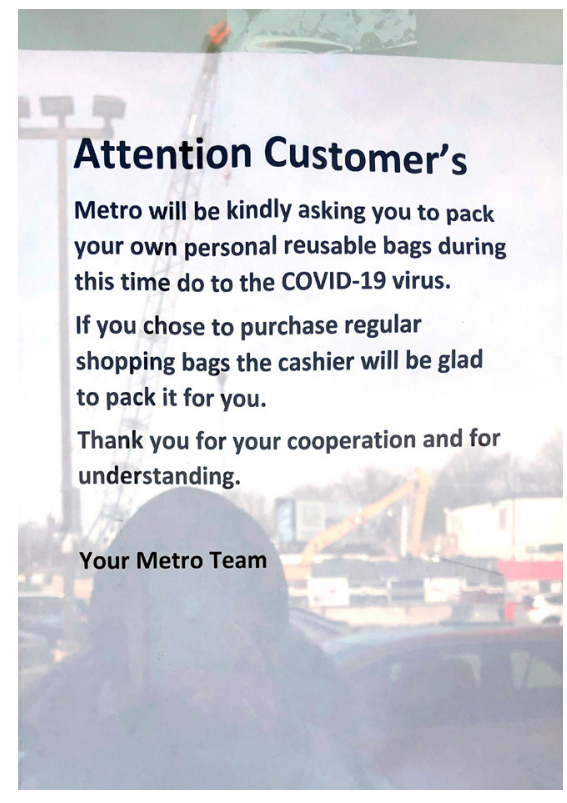

Figure 11

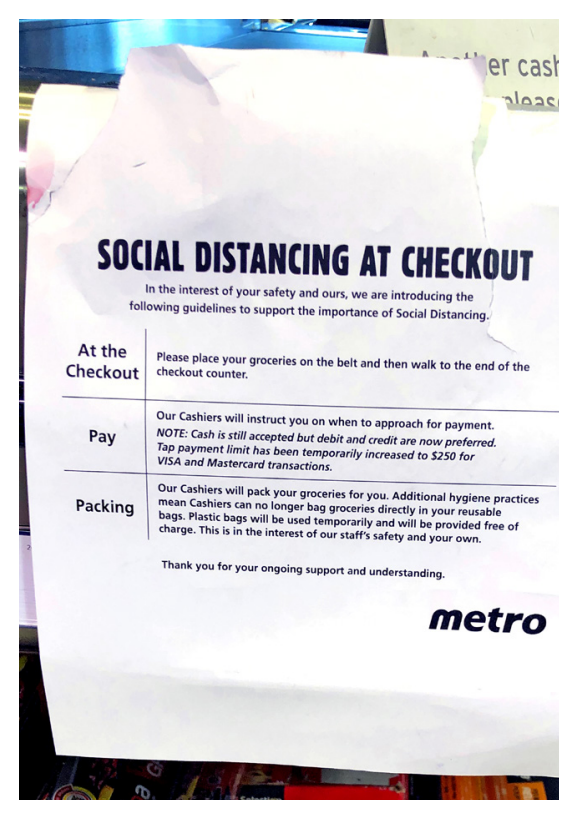

Figure 12

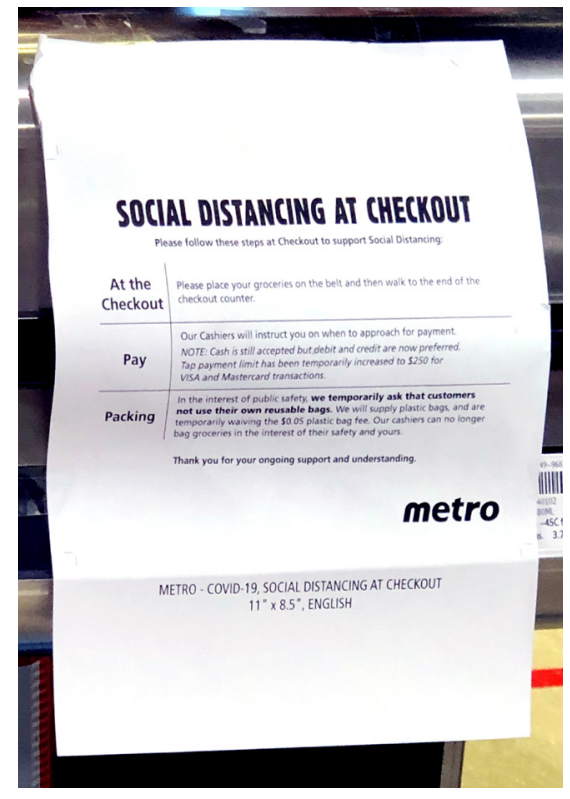

Figure 13

Initially, the information about social distancing provided to consumers was general. However, shopping became a specific activity that required more elaborate rules as the pandemic wore on. By mid-March, informal signs outlining nine actions for social distancing in grocery stores, were taped to store windows and doors. By the end of March, to reinforce the information, poster-stands near the store entrance that normally hold promotional flyers was repurposed, to offer customers copies of the sign to take home. 


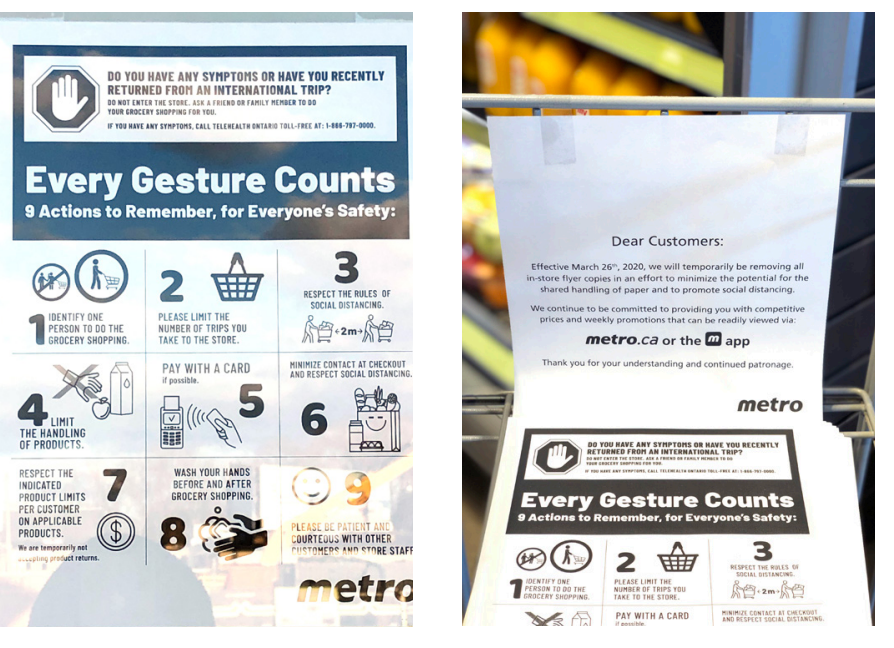

Figures 14 and 15

By April, informal signs were beginning to be replaced with professional, poster-sized signs and often produced in the brand colors of the retailer. These signs were posted and placed in stands outside the store. Often, the original informal sign remained taped to the window remain right behind the new sign stand (see Figure 16). Some retailers announced that weekly printed flyers would no longer be printed and delivered, and instead presented product information and pricing only on their website or app. Recognizing that not all customers would have access to the digitized information, and that paper flyers support memory and motivate purchase, poster stands were repurposed to hold eight sheets of printer paper with the product and price deals of the week, taped to a piece of cardboard (McNeish 2019; Ziliani et al. 2019) (Figure 17).
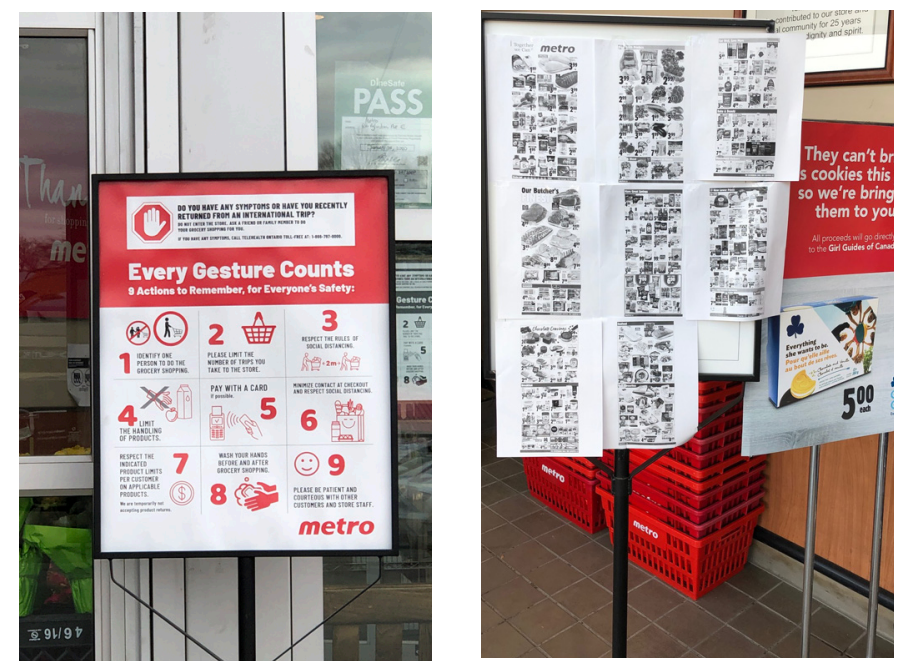

Figures 16 and 17

\section{Customer Uncertainty}

It took time for some retailers, ones that remained open, to realize the level of customer uncertainty. Stating that they were open, indicating their services, and their hours of operation were three basic messages retailers chose to post in signs. Unfortunately, the use of small font muted the message's impact, as they were largely unreadable from a distance. While most signs were on standard white printer paper, a few were colored and the use of color in the midst of several white signs drew more attention. It is not clear if retailers intended to do this. In Figure 19, the pink sign had font large enough to read from two meters away ("Curbside Pickup. Other Entrance"). One sign using a yellow colored but larger font was difficult to read, even close up (Figure 18).
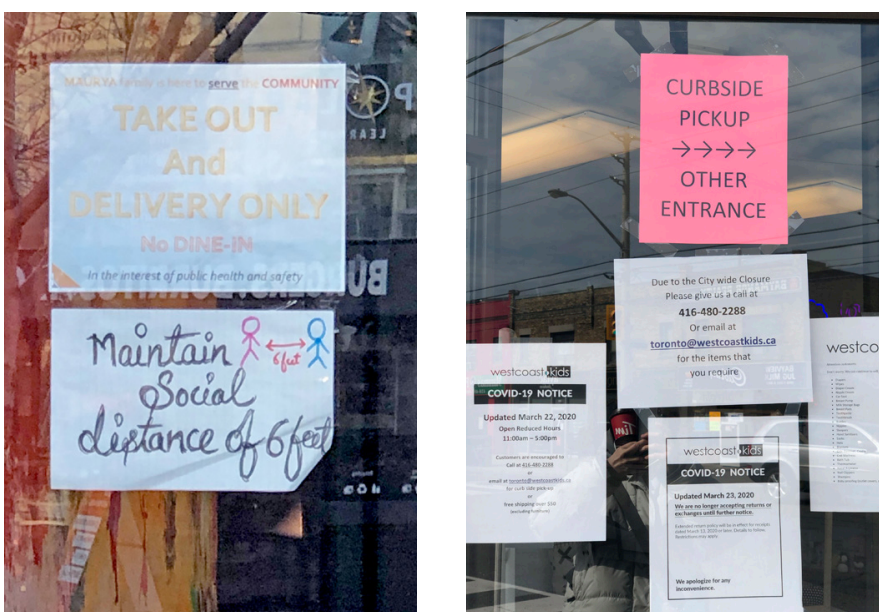

Figures 18 and 19

Multiple informal signs printed in small font resulted in a visually messy and unorganized presentation of information. It is hard to know whether this was a deliberate action, but one can only speculate as to why many small retailers added additional informal signs rather than removing some or consolidating the information onto larger professionally made signs. They may not have had access to the financial means to hire a company to design and print poster size signs.

In addition, the stress of the situation could mean that they perceive signs to be less important than other aspects of their business. Regardless of their reasons, it has the effect of increasing the cognitive load on 


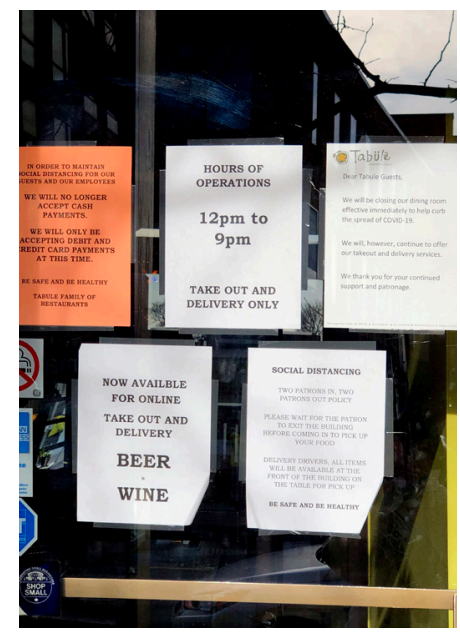

Figure 20

consumers during a stressful time and may contribute to customers' confusion around these retailers' status.

Over time, some businesses realized that they needed larger signs that could be read from a distance and that would attract customers' attention. As was true in March, stores used materials they had on hand. Although the promotional strategy may have been similar, that is, to draw attention to the fact the store was open, stores used different approaches. Some added additional signs alongside, or even over top of the original ones and some, but not all, used a larger font.

One retailer added a larger handmade sign that was mounted over the original smaller signs. The message was printed on cloth and stuck to the window with several pieces of grey duct tape. While the lettering and appearance is child-like and haphazard, the wording is formal: "I assure you, we're open!" It also indicates the services being provided in order to avoid customer confusion or misunderstanding, "For takeout and delivery."

As of April 4, pet stores were only allowed to operate via curbside pick-up or home delivery. One pet food store, presenting the message "We are open," used nine sheets of white printer paper, printing one letter per sheet to create the impression of a singular large 'sign.' As noted was often the case, the original sign posted a month earlier remains in the window (Figure 21).

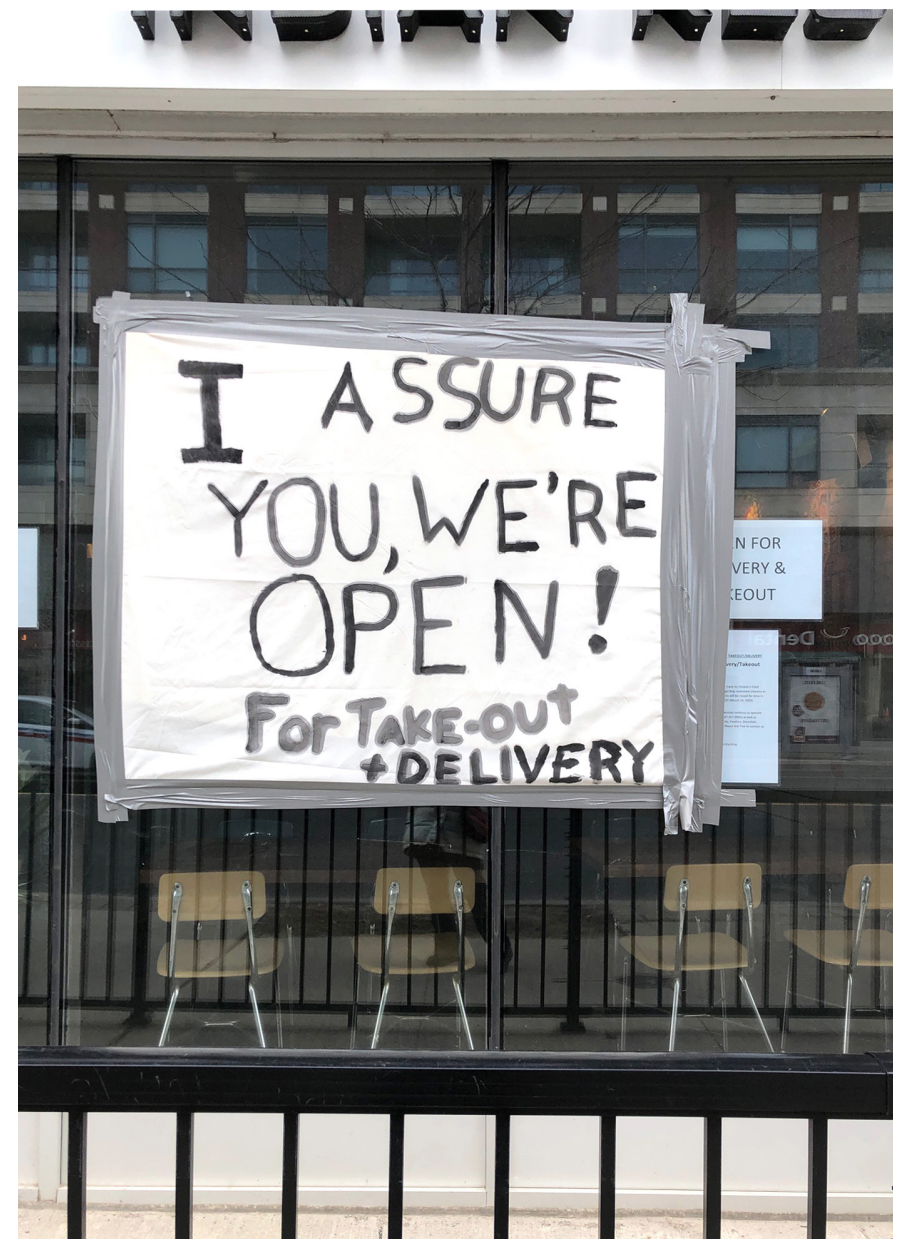

Figure 21

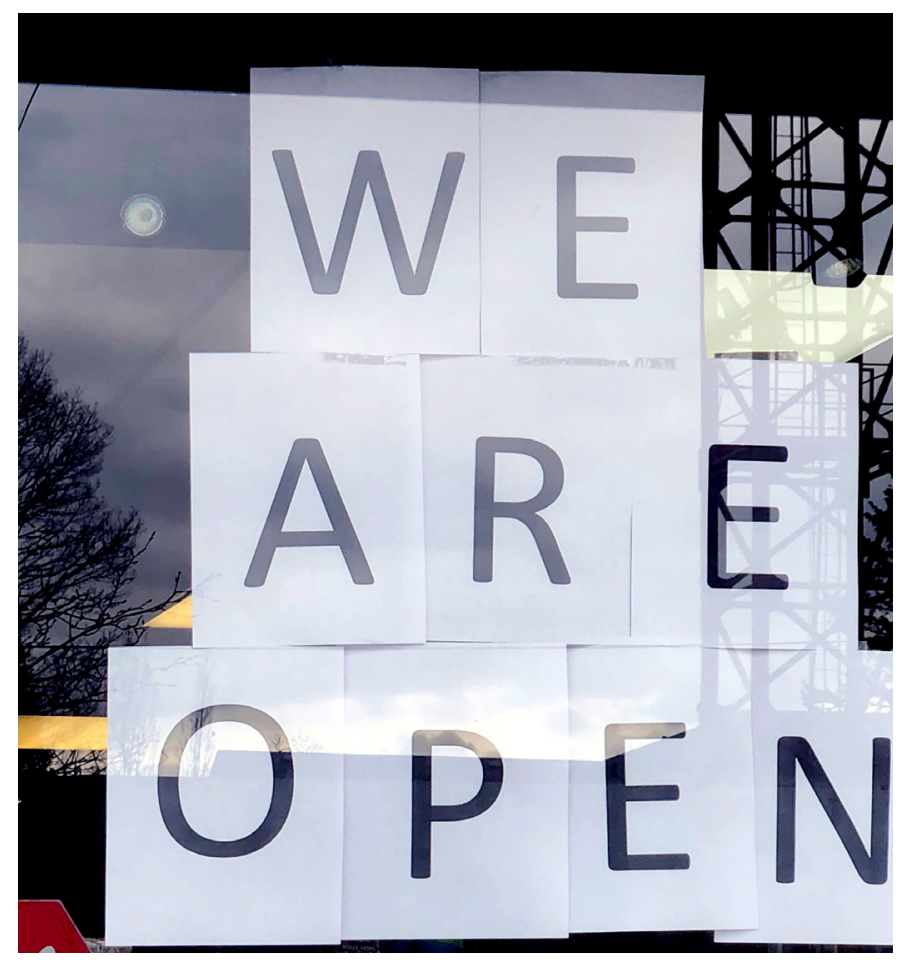

Figure 22 
Dollarama, a multi-location discount store that was permitted to stay open because it sells food, handwrote a message on four green neon colored heavy paper stock that stood out and conveyed the message that "We are open!" With two store locations in the area of study doing the same thing, it appears as if these informal signs were part of the communication strategy of the Dollarama chain.

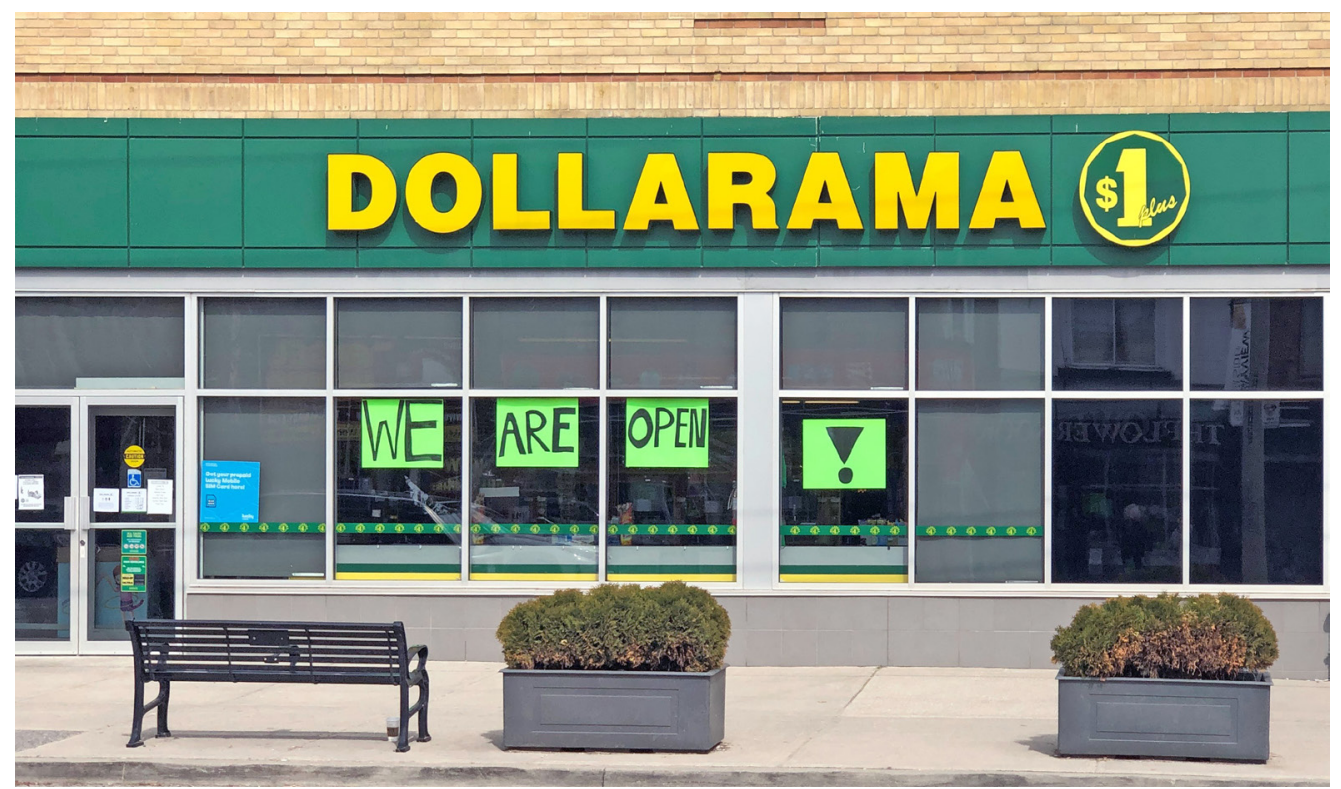

Another retailer's sign indicated that they offered free local delivery, along with their phone number in a font large enough to be read across the road. The use of a serif font and wide tracking and leading, allowed for a more legible sign, as compared to others. The combination of serif font and more spaced meant this sign was more readable and effective than other signs.

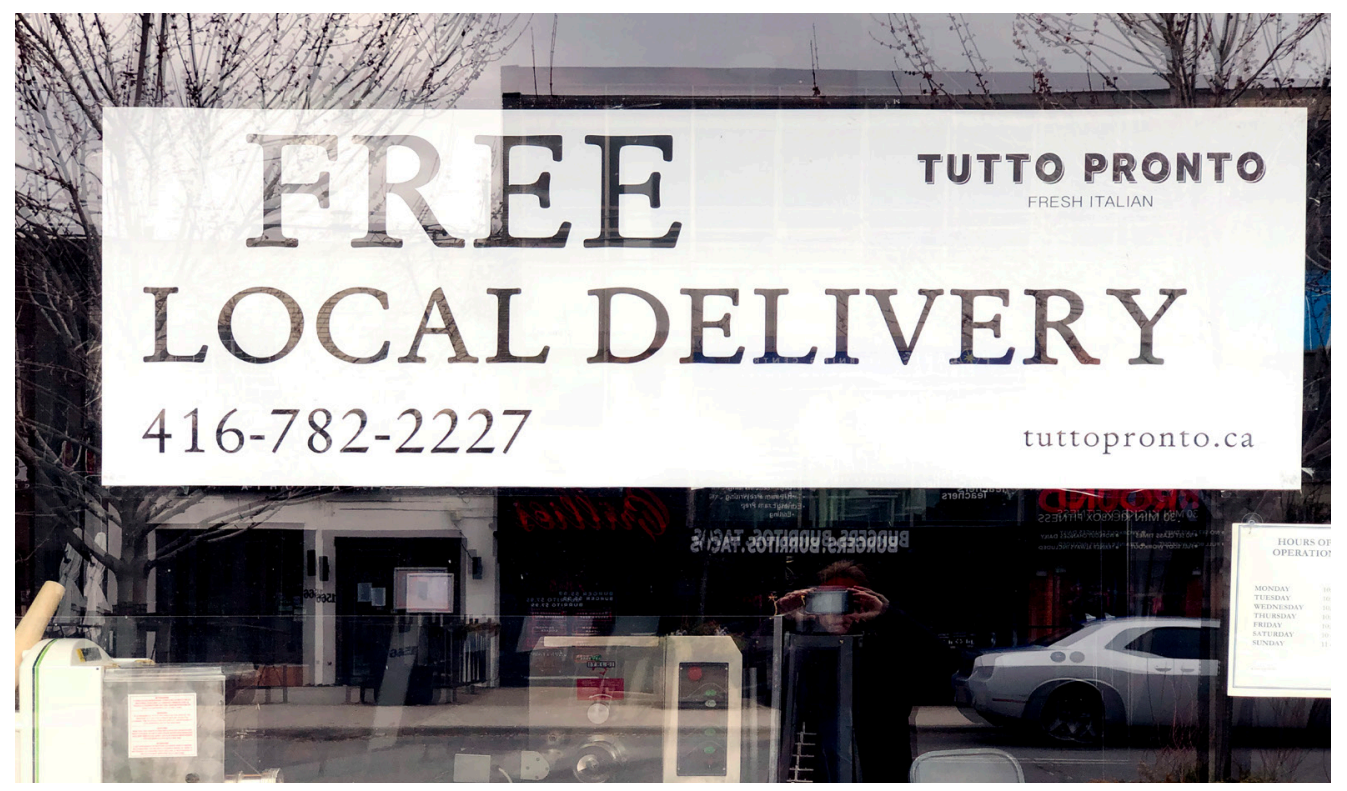


By the end of March, public health agencies and government websites made available a number of standardized signs to communicate COVID-19 symptoms and social distancing behaviors (Government of Canada 2020). Unlike their large counterparts, very few small businesses, whether open or not, posted these signs.

Multi-location retailers have an advantage by being able to hire specialized employees who are skilled at developing signage and messaging. As a result, by April most had transitioned to corporate poster-sized signs that used color to attract attention and large font readable from two meters away for the key messages. Professional signs convey the necessary information in an organized visually appealing way, whereas informal signs are more disorganized in their construction.
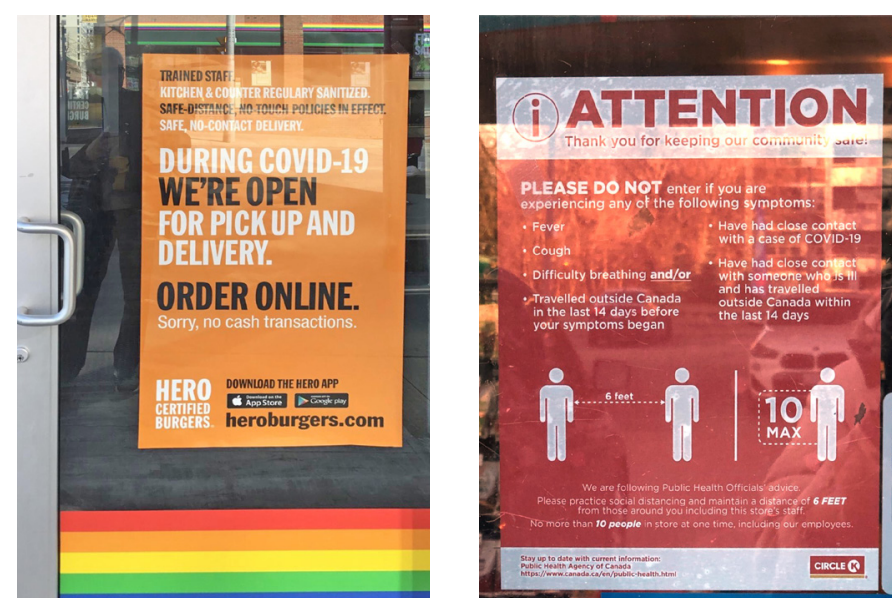

Figures 25 and 26

As the rules of social distancing were modified, retailers continued to remind customers not to enter the store if they had COVID-19 symptoms, to practice social distancing, and to use signs to indicate the maximum number of people allowed in the store at any one time. Professional signs accomplish this through cohesive color and font schemes and the use of multiple font sizes and capitalization. Pictograms indicate the required spacing between people and the number of customers allowed in the store at any one time. Professional signs generally convey more information more clearly than informal signs, however, some of the font size and colors were unreadable at a distance.
By April, large businesses had replaced some of the informal signs with professional ones. Inside grocery stores, for example, shelf signs were added to remind customers about social distancing. Key messages in brand colors and fonts, were printed on heavy paper stock, laminated, and hung with plastic shelf hangers. Side by side with these professional signs were some of the informal signs. There could be several reasons for using both informal and professional signs. These include the cost and effort to design and produce the professional signs or perhaps the uncertainty as to whether the information will be soon outdated. I speculate that professional signs reflect information, social distancing measures, for example, that retailers believe will hold true for months, whereas informal signs are for information about short-lived situations.
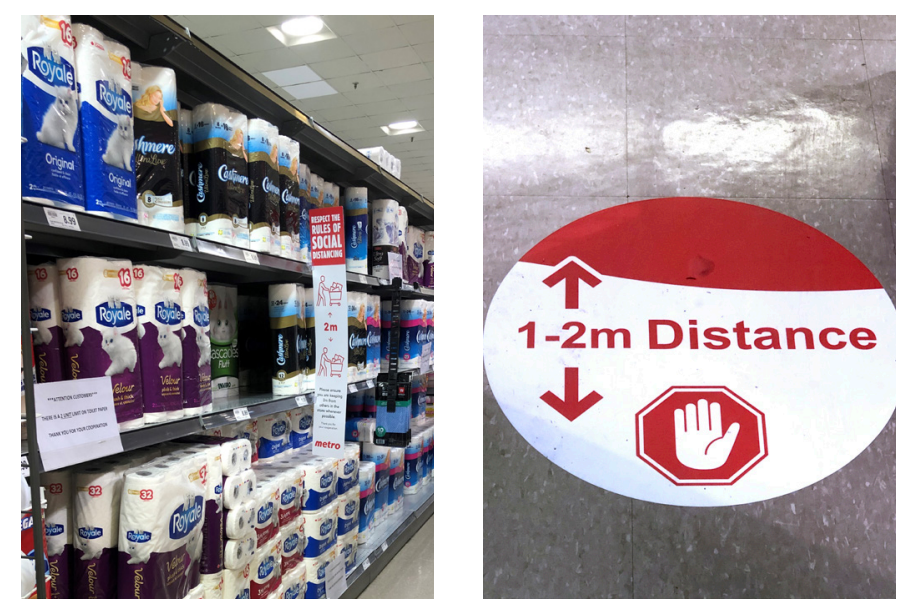

Figures 27 and 28

Further supporting the efforts to educate and reinforce social distancing to customers, branded decals appeared on floors along with duct tape to mark direction of travel in the store, or to ensure adequate side-to-side spacing for passing. Early on, various colors of duct tape was used to indicate twometer spacing and where to stand while waiting in line. In some stores, two different colors of duct tape were used, especially near the check-out stations, to communicate how to maneuver in a space that could be prone to crowding.

By early April, red tape and red circular decals became standard for large stores. A few, red-brown rectangular decals were observed, often at the entrance, at times combined with circular decals. The use of circular 


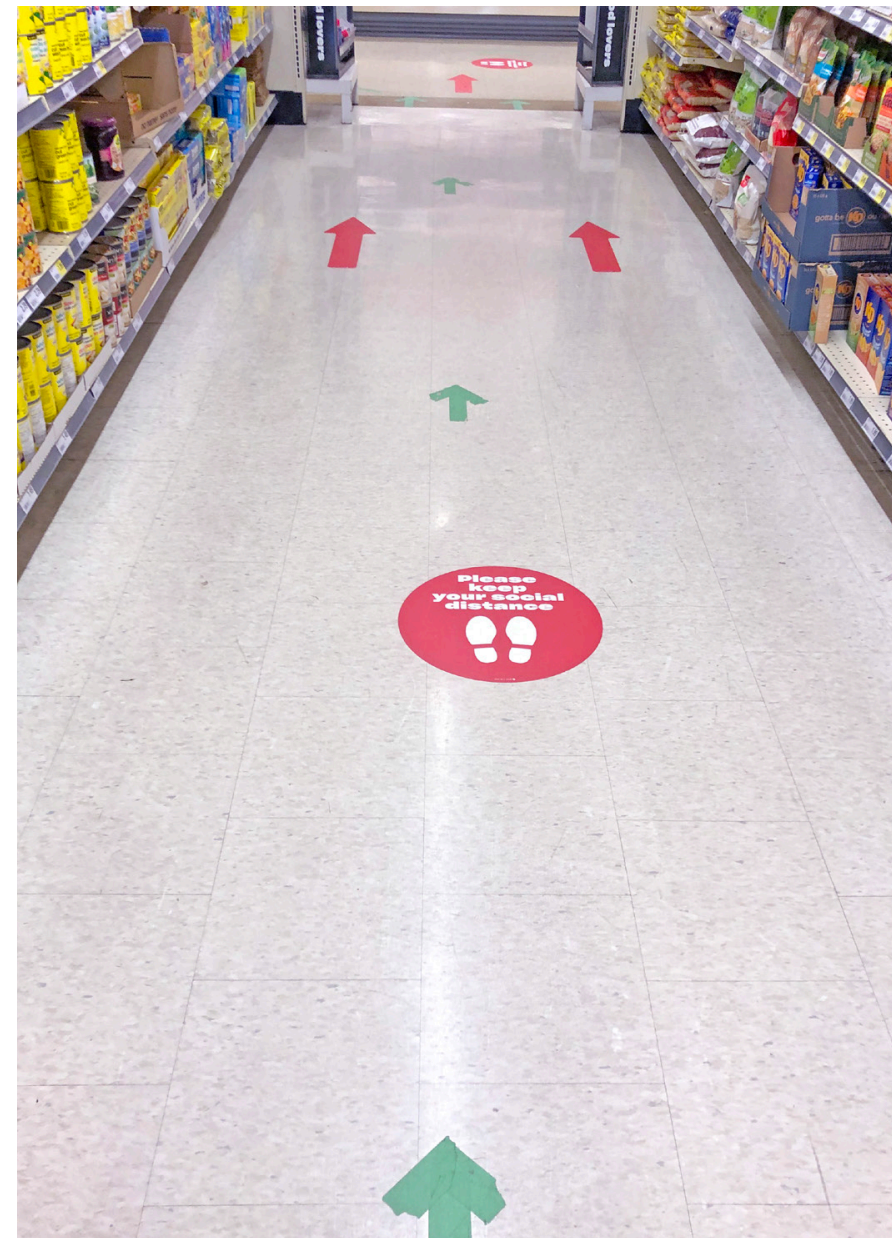

Figure 29

deals may not be accidental. They may have been designed deliberately, to remind the viewer of a red traffic stop sign. The assumption being that customers would be familiar with the required action, that is, to stop and look before proceeding further.

In the early stages of the pandemic, customers moved freely in and out of retail locations. The informal signs were typically on interior doors with none on the exterior doors. Photographs taken at a pharmacy show six informal signs on an interior door. As conditions changed, professional signs appeared on the exterior door (see Figures 31 and 32). The signs asked customers to consider whether to enter or not (due to COVID symptoms), pictograms limiting the number of customers in-store, and to stay six meters apart. The early signs were all text while the professional signs are larger and include pictograms. The informal sign communicating the reduced store hours was moved from the interior door to the exterior door.

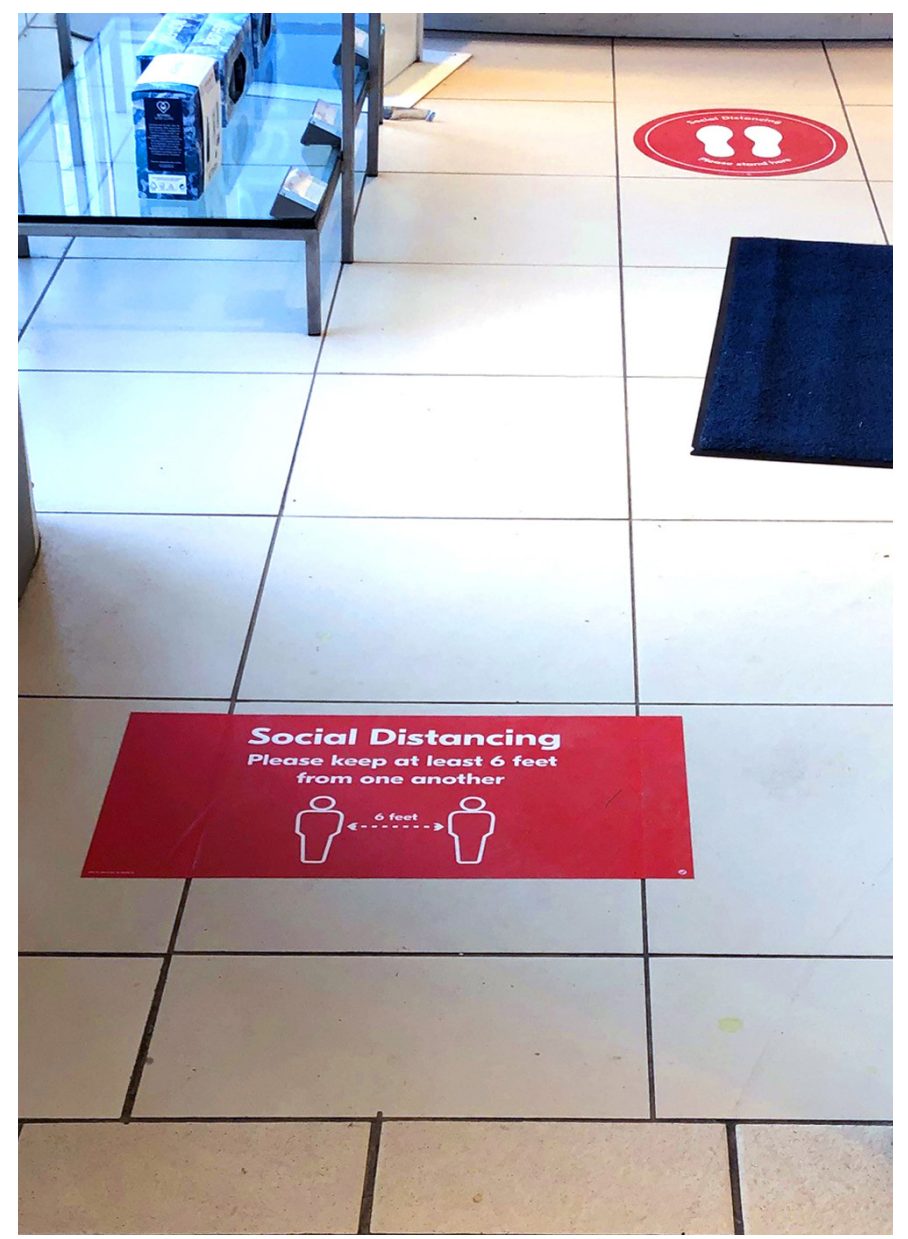

Figure 30

Multi-location businesses that remained staffed, but closed to customers, transitioned to customer pick-up, and delivery to home. Initially, informal signs were used to explain the process to customers. Over time those were replaced with professionally designed and made ones. Whether inside the store or out, duct tape was the most often observed choice for marking the direction of travel and to indicate where to stand (see Figures 33 and 34).

\section{DISCUSSION}

In the first quarter of 2020, COVID-19 began to significantly impact countries across the world. In a few short weeks, people's normal social behavior had to be changed in order to stop the spread of the disease. Government directives are abstractions until people see tangible manifestations of them or have personal experience of them. While governments mandated social distancing behaviors, it was up to retailers to determine how to implement and communicate them 


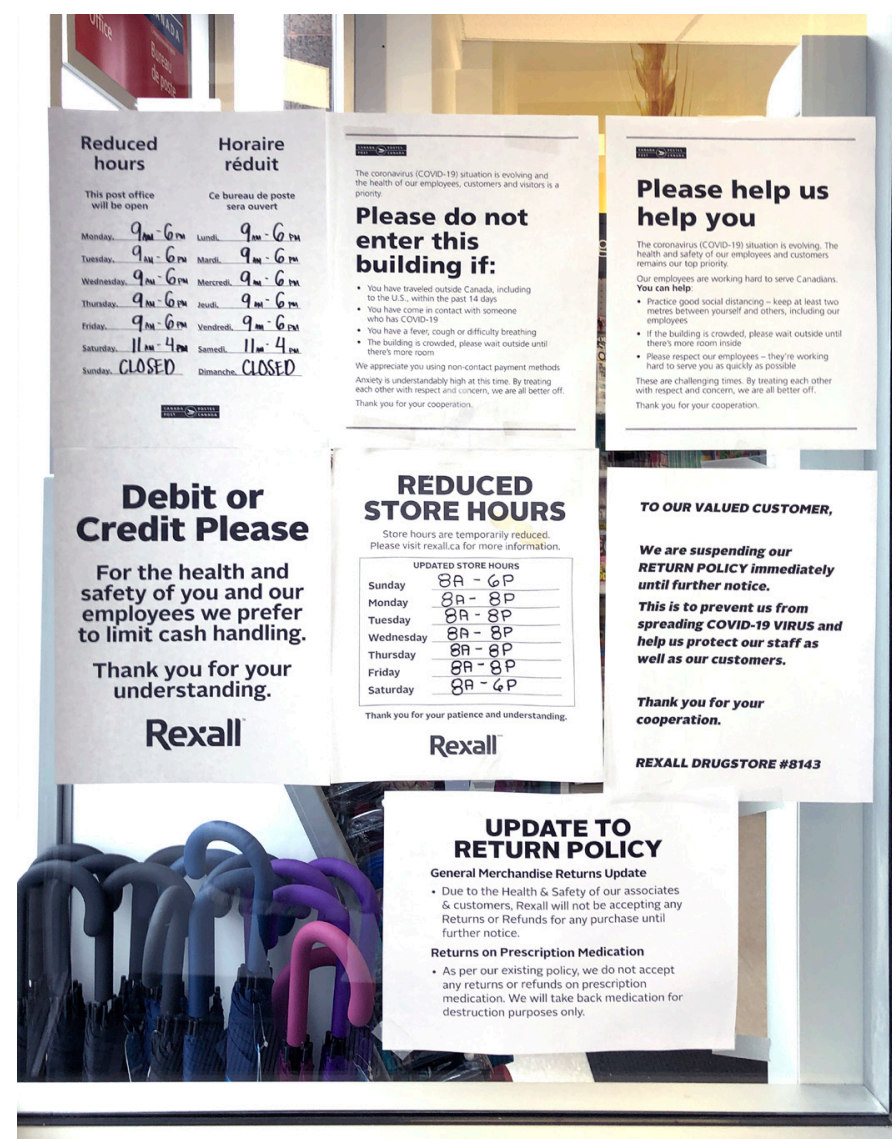

Figure 31

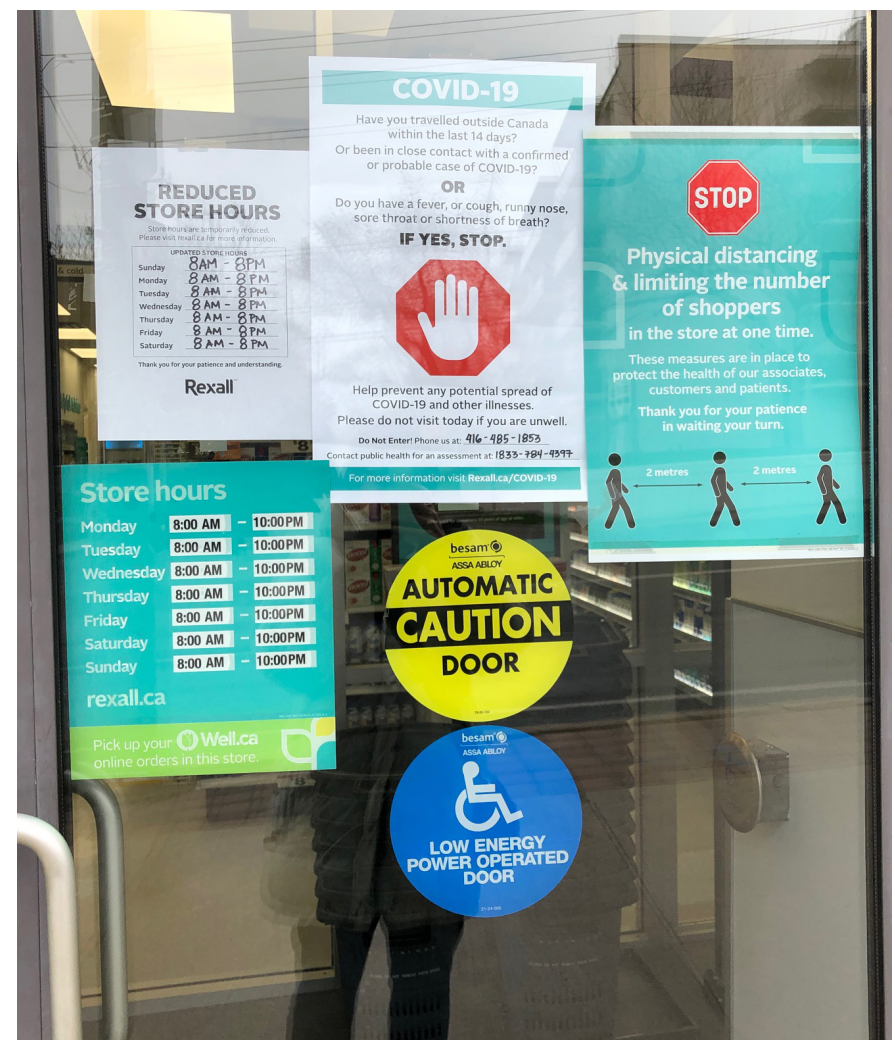

Figure 32 to customers and employees. One could argue that the retailers acted only to avoid the fines and penalties put in place by the government (News Staff 2020). Alternatively, one could say that retailers demonstrated corporate social responsibility and that their efforts in creating and posting signage was an integral part of creating awareness of and reinforcing new and evolving social distancing behaviors.

Schwabe and Wolf (2009) report that stress reduces comprehension of new information. Prompts such as signs, when presented in an uncertain and constantly changing situations, must be easy to follow and placed close to where behaviors will occur (Werner, et al. 1998). The informal signs that appeared early in the pandemic represented retailers' interpretation of what was required, made customers aware that shopping had changed and educated them about new norms. The signs explained store policies, indicated stockouts or restrictions on the number of products that customers could purchase, provided guidance where to stand, and how to move around the store, while maintaining social distancing.
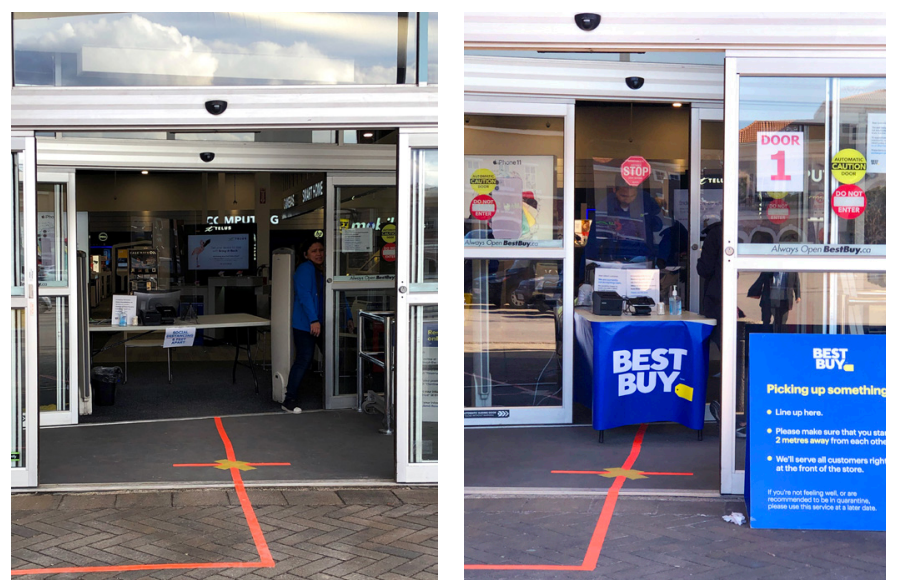

Figures 33 - 34

In previous situations (e.g. adding calorie count to menus and in-store signage) larger retailers had an easier time complying with government regulations because of the greater financial and personnel resources available to them (Moghimi and Wiktorowicz 2019). In the case of COVID-19, the situation changed so rapidly that there was no size advantage to initially, at least, in terms of informal signage. 
Printer paper was the ideal material in the early stages of the pandemic. Signs made of paper could be replaced frequently to respond to changing guidelines at negligible cost. Using regular tape, they could be attached to doors, windows, and throughout the store. However, paper has its disadvantages. The Canadian weather in the spring can vary dramatically and inclement weather like rain, snow, and wind adversely affects papers longevity. Weather notwithstanding, it is simply not robust enough for long term use. The use of paper without some sort of protection, such as a plastic sleeve, suggests that retailers considered the situation temporary, or as is often true in a crisis, protecting paper from the elements was not a priority.

Almost all of the informal signs were printed on $8.5 \mathrm{x}$ 11 white printer paper, suggesting that office printers or photocopiers were readily available at the retail location. Sundar and Kellaris (2017) find that the font color used in a logo affects the consumer's perception of a retailer. Most informal signs used black, small, and sans-serif font on unlined paper and using black font is likely the result of cost and the availability of black-only printers in retail locations. Additionally, in this situation, it seems an appropriate choice as black font may have communicated to customers that the business was taking the situation seriously and acting professionally.

Ease of comprehension is particularly important when people are distracted and struggling to retain new and changing information (Juni and Gross 2008). Thus, the use of small and sans-serif fonts is a suboptimal approach. Small font is unreadable unless the viewer is close to the sign and without lines on paper, a sansserif font can appear to float. Per Craig et al. (2006) rows of text in serif font are more legible and easier to comprehend, and since the viewer can focus on comprehending the message, their recall is improved (Glasser et al.2005). Studies have found that some of the positive results for serif were the result of combining it with slightly wider letter distance, larger size, or row height (Moret-Tatay and Perea 2011). Using serif, black, and larger fonts improves sign readability. The font should be large enough to be legibly communicate to passersby from two meters away, and to allow the maintenance of the correct amount of physical distance from customers entering or leaving the store.

Once retailers ascertained which social distancing measures would continue, informal signs began to give way to professional ones. Multi-location retailers that remained open worked to standardize the customer experience over the store network. The government also assisted retailers' efforts by making information available on their websites in the form of printable documents (Government of Canada 2020). Professional signs proved to be more robust, as they were laminated or coated, and printed on heavier stock that could stand up to daily abuse and the Canadian climate. By increasing the size of the signs, the readability from a distance for those passing on the sidewalk or road was improved, and key information could be consolidated on a single sign rather than multiple smaller ones.

The type of signs used by retailers could also be considered a reflection of their emotional state. The first emotions of uncertainty and unknowing were over time replaced by "certainty and knowing." The informal signs, signaling frequently changing information, used early in the pandemic were subsequently replaced by professional signs that signaled "business as usual" with less frequently changing information as the pandemic continued.

While some retailers removed the informal signs, curiously others added professional signs alongside the original ones. Do the informal signs continue to exist in the same way as physical landmarks, such as rock formations, rivers, or mountains? In the past, these physical landmarks would have been the only signs for wayfinding, as was true in the early stage of the pandemic, but in modern times, co-exist with the professional signs for wayfinding in, for example, national parks or nature trails (Sarjakoski et al. 2013). Could it be that the informal signs have become part of the "landscape" of the new world of COVID?

Rahman and Mehta (2020) comment that signs are an important part of place-based communication in that they may reflect the nature of the neighborhood. However, when non-local retail brands enter, their signs may or may not reflect the nature of the 
neighborhood. Consistent with this, a majority of the informal signs used by single-location retailers seemed to convey a sense of community and caring in terms of their customers and employees. They were often emotional in tone, conveying regret for closing, gratitude to the community, and with well-wishes for the safety of the reader. In contrast, the majority of the informal signs used by large multi-location retailers were educational and practical. They conveyed facts about the behavior expected from their employees and customers.

Most single location retailers that closed did not provide their customers with alternative methods of contacting them, and adding a phone number, email, or a social media account to their informal signs would have given customers a chance to stay connected with retailers throughout the crisis. Since their signs communicated that they viewed themselves as part of the community, local retailers adding contact information to their signs is something they should consider in future crisis management planning. It is important to acknowledge that most small retailers, unlike large retailers, do not have employees dedicated to communication and crisis management planning. In addition to their specialized corporate workforce, large retailers have a comprehensive digital footprint with many ways to connect with customers. Using transactional websites or apps, customers continued to purchase products and services from them, thereby facilitating their ability to continue to operate even when closed to in-person customers, while small retailers without that infrastructure had to completely shut down.

Some readers might find it surprising that paper signs were preferred to digital signs. While single location retailers are generally less likely to have digital signs, multi-location retailers commonly use digital signs to present products, services, pricing, and promotional information in normal conditions (Roggeveen, Nordfält, and Grewal 2016). Rather than use them to provide up-to-date COVID-19 information, digital signs continued to display pre-pandemic advertising.

There are several possible explanations for not using digital signs during the pandemic. It could be that the cost and size of digital signs prohibits their placement in multiple locations inside and outside the store (Xnage 2020). The variation in regulations between geographic locations would have required different content and that could make it difficult to create and post the correct information in rapidly changing circumstances. It could also be that the technical expertise required to update the signs was deployed to other tasks such as maintaining store operations or getting non-essential employees set up to work from home. In March it was reported that there were little readily available COVID-19 content or necessary software code for digital signs (Haynes 2020). By mid-April while companies began advertising the necessary content and software code, digital signs remained COVID-19 content free.

Badami (2018) writes about the Indian practice of "jugaad," which expresses the idea of objects repaired, repurposed or re-engineered. Interest in this practice, which is commonplace in poorer countries, emerged as an economic and sustainable practice in wealthier ones following the 2008 financial crisis. The practice of repurposing printer paper as signs, duct tape placed on sidewalks and floors to indicate direction of travel, and equipment such as poster and flyer stands used in unexpected ways, emerged during the pandemic. Given the uncertainty and rapidity of events, repurposing equipment became another coping mechanism for retailers to manage their operations and communication efforts.

While one can hope that a crisis of this magnitude will not occur again, companies and governments often face crises that require rapid communication during events such as earthquakes, floods, or hurricanes and in their immediate aftermath. Paper signs, along with pens / markers and duct tape can be rapidly deployed in these circumstances, as a way to identify where buildings or people are located, give directions, provide updates as to the state of events, and inform citizens of safety regulations. Aside from future crises, as governments begins to open their economies, retailers that have been closed will need to learn how to operate under the conditions of social distancing. Among other operational changes, they will need to learn how to use signs effectively. 
LIMITATIONS OF RESEARCH AND

\section{SUGGESTIONS FOR FUTURE RESEARCH}

The data collected for this study was limited to one area within walking distance of the principal researcher's home the result of the restrictions imposed by the Canadian government during the COVID-19 crisis. The language and content posted on the signs will likely vary across geographic areas and follow-up research in other geographic areas could be done using the photographs of informal signs found in many media stories posted online (see Carlberg 2020; Fortin 2020; Mercer 2020; Toh 2020).

Given the seriousness of the situation, the author did not feel it appropriate to talk with retailers or solicit customer input about posted signs. Followup research with retailers to explore why both small, single location and large multi-location businesses chose to use paper signs is future research avenue. One should not overlook the functional qualities of paper (easy to produce, easy to change) and its low cost compared to professional signs to explain their use by retailers. In addition, retailers may have decided that with information changing rapidly, committing to professional signs was not practical. Also, the number of retailers demanding signs compared to the ability of printing companies to produce the required number in a timely fashion may have contributed to the limited supply of professional signs.

While this research documented the objective characteristics of signs during COVID-19, follow-up research with customers could assess the subjective properties of the signs. Kellaris and Machleit (2016) propose the following characteristics: attractiveness, perceived quality, novelty / familiarity, interestingness, perceived complexity, legibility, perceived clarity/ ambiguity, congruity with expectations (or surprisingness), and congruity (or incongruity) with architecture or surrounding environment ("aesthetic congruity"). Further, now that some companies are using professional signs to communicate social distancing behaviors, it would be interesting to consider the effect on brand image. Huddleston et al. (2015) demonstrated that store signage is linked to brand image and positive purchase intent. One might wonder if retailers are connecting their brand to a negative event, or alternatively are demonstrating corporate social responsibility, and reassuring customers that, with retailers' signs returning to normal, their lives may also start to be more predictable. Finding out why retailers did not use their digital signs to present COVID information would be a first step to understanding their place in future crises. If it were the case that digital signs commanded technical resources that were deployed elsewhere, an opportunity to develop more easily programmed digital signs presents itself.

Retail signs not only helped people understand what to do and how to behave, but they provided a way to navigate the new and unfamiliar world of a global pandemic. Physical signs provide the viewer with information to help them make a decision when they are uncertain how to proceed (Mollerup 2005). Thus, it is fitting that an old technology, paper, was the dominant material used to create ad-hoc retail signs. Paper's fragility may have simultaneously reflected the uncertainty that people felt in the early days of the pandemic, while its familiar and timeless presence may have provided a sense of emotional security and direction. 


\section{REFERENCES}

Adam A. and Jensen J. D. (2016). What is the effectiveness of obesity related interventions at retail grocery stores and supermarkets? A Systematic Review. BMC Public Health 16(1), 1247-1271.

Aaronson, S. A. (2003). Corporate responsibility in the global village: The British role model and the American laggard. Business and Society Review 10(3), 309-38.

Badami, N. (2018). Informality as fix repurposing jugaad in the post-crisis economy. Third Text 32(1), 46-54.

Beck, L. (2020). "How to stock your pantry if you're worried about a coronavirus quarantine. Globe and Mail, 6 March. https://www.theglobeandmail.com/life/health-and-fitness/article-how-to-stock-your-pantry-if-youre-worried-about-a-coronavirus/

Benzie, R. (2020). "Disobeying the covid-19 emergency law could cost you \$100,000 and one year in jail." The Toronto Star, 31 March. https://www.thestar.com/politics/federal/2020/03/31/disobeying-the-covid-19-emergency-law-could-cost-you-100000-andone-year-in-jail.html

Brown, D. (2020). "Individuals, businesses that defy emergency orders could be fined." CBC News, 20 March. https://www.cbc.ca/news/ canada/toronto/opp-warns-businesses-social-distancing-1.5505439

Calabretta, D. (2020). "Panic buying and hoarding begins." Strategy, 14 March. https://strategyonline.ca/2020/04/23/metro-wants-people-to-get-through-the-pandemic-together/

Carlberg, A. (2020). "Signs posted outside Toronto restaurants show new normal." blogTO, 11 April. https://www.blogto.com/eat_ drink/2020/03/signs-posted-outside-toronto-restaurants-show-new-normal/

Carpenter, J. M. and Moore, M. (2006). Consumer demographics, store attributes, and retail format choice in the US grocery market. International Journal of Retail and Distribution Management 34(6), 434-452.

City of Toronto. (2016). "Ward 15-Don Valley West." Canadian Census Data. https://www.toronto.ca/city-government/data-research-maps/neighbourhoods-communities/ward-profiles/ward-15-don-valley-west/

Craig, J., Scala, I. K. and Bevington, W. (2006). Designing with Type: The Essential Guide to Typography. New York: Watson-Guptill.

Da Silva, R. V. and Alwi, S. (2006). Cognitive, affective attributes and conative, behavioral responses in retail corporate branding. Journal of Product and Brand Management 15(5), 293-305.

Declerq, K. (2020). “Ontario corporations, individuals could face 'staggering' fines for price gouging." CTV News, 30 March. https://toronto.ctvnews.ca/ontario-corporations-individuals-could-face-staggering-fines-for-price-gouging- 1.4872588

Donnelly, A. (2020). "What Canada is doing to contain COVID-19 as coronavirus inches closer to being declared a pandemic." National Post, 28 February. https://nationalpost.com/health/what-canada-is-doing-to-contain-covid-19

Fortin, J. (2020). "Starbucks goes from sip and stay to grab and go." New York Times, 16 March. https://www.nytimes.com/2020/03/16/ business/starbucks-to-go-coronavirus.html

Gasser, M., Boeke, J., Haffernan, M. and Tan, R. (2005). The Influence of Font Type on Information Recall. North American Journal of Psychology 7(2), 181-188.

Government of Canada. (2020). "Coronavirus disease (COVID-19): Awareness resources." 26 March. https://www.canada.ca/en/public-health/services/diseases/2019-novel-coronavirus-infection/awareness-resources.html

Harris, R. (2020). “How will our grocery supply chain weather the pandemic?” Canadian Grocer, 5 June http://www.canadiangrocer.com/ worth-reading/how-will-our-grocery-supply-chain-weather-the-pandemic-95311

Haynes, D. (2020). “Wanted and needed: coronavirus PSAs that digital signage networks can use." Sixteen-Nine, 10 March. https://www. sixteen-nine.net/2020/03/10/wanted-and-needed-coronavirus-psas-that-digital-signage-networks-can-use/

Huddleston, P., Behe, B. K., Minahan, S. and Fernandez, R. T. (2015). Seeking attention: An eye tracking study of in-store merchandise displays. International Journal of Retail and Distribution Management 43(6), 561-574.

Jenkins, R. (2020). “Coronavirus: the stages of public concern." Polling Guru, 1 April. http://pollingguru.ca/coronavirus/

Juni, S., and Gross, J. S. (2008). Emotional and persuasive perception of fonts. Perceptual and Motor Skills 106(1), 35-42.

Kaspar, K., Wehlitz, T., von Knobelsdorff, S., Wulf, T., Antoinette, M. and von Saldern, O. (2015). A matter of font type: The effect of serifs on the evaluation of scientific abstracts. International Journal of Psychology. 50(5), 372-378.

Kellaris, J. J. and Machleit, K. A. (2016). Signage as marketing communication: A conceptual model and research propositions. Interdisciplinary Journal of Signage and Wayfinding 1(1), 1-17. 
Khachatryan, H., Rihn, A., Behe, B., Hall, C., Campbell, B., Dennis, J. and Yue, C. (2018). Visual attention, buying impulsiveness, and consumer behavior. Marketing Letters 29(2), 23-35.

Leger. (2020). "How concerned are Canadians about the Coronavirus?: A Leger poll.” 14 February. https://leger360.com/surveys/canadians-concerns-about-the-coronavirus/

Lehman, P. H. and Geller, E. S. (2004). Behavior analysis and environmental protection: Accomplishments and potential for more. Behavior and Social Issues 13(1), 13-32.

McCarthy-Tetrault (2020). “COVID-19: Emergency measures tracker.” https://www.mccarthy.ca/en /insights/articles/covid-19-emergency-measures-tracker.

McNeish, J. (2019). Paper Flyers in the Age of Social Media. Conference on Historical Analysis and Research in Marketing (CHARM): Exploring Identity Building: Marketing History as an Instrument of Transformation 19, 380-383.

Mercer, J. (2020). "Signs of the times: a study of COVID-19 business closure notices in St. John's." The Telegram, 8 April. https://www. thetelegram.com/news/local/signs-of-the-times-a-study-of-covid-19-business-closure-notices-in-st-johns-435524/

Mollerup, P. (2005). Wayshowing. A Guide to Environmental Signage Principles and Practices. Baden: Lars Muller.

Moret-Tatay, C. and Perea, M. (2011). Do serifs provide an advantage in the recognition of written words? Journal of Cognitive Psychology 23(5), 619-624.

Moghimi, E. and Wiktorowicz, M. E. (2019). Regulating the fast-food landscape: Canadian news media representation of the healthy menu choices act. International Journal of Environmental Research and Public Health 16(24), 4939-4960.

News Staff. (2020). “Torontonians face up to \$5k fine for violating physical distancing by-law." CityNews, 2 April. https://toronto.citynews. ca/2020/04/02/torontonians-face-up-to-5k-fine-for-violating-physical-distancing-by-law/

Ontario Government. (2020). “List of essential workplaces”" 3 April. https://www.ontario.ca/page/list-essential-workplaces\#section-3

Ontario Government. (2020). O. Reg. 82/20: Order Under Subsection 7.0.2 (4). Closure of Places of Non-Essential Businesses under Emergency Management and Civil Protection Act, R.S.O. 1990, c. E.9, Versions: April 16, 2020-May 6, 2020; April 9, 2020-April 15, 2020; April 3, 2020-April 8, 2020; March 24, 2020-April 2, 2020. https://www.ontario.ca/laws /regulation/200082

Ottawa Public Health. (2020). SFOA 2017 Guide for Retailers (updated 2020). 3 January. www.ottawapublichealth.ca/en/public-health-topics/resources/Documents/SFOA-2017-Guide-for-Retailers-2020---2020-01-28.pdf

Public Health Agency of Canada. (2020). “Coronavirus Disease (COVID-19).” https://www.canada.ca/en/public-health.html

Quill (n.d.). "When to use multipurpose paper vs. copy paper.” https://www.quill.com/content/index/paper-buying-guide/paper-comparisons/default.cshtml

Rahman, M. N. and Mehta, V. (2020). Signage form and character: A window to neighborhood visual identity. Interdisciplinary Journal of Signage and Wayfinding 4(1), 35-48.

Ray, J. L. and Smith, A. D. (2012). Using photographs to research organizations: Evidence, considerations, and application in a field study. Organizational Research Methods 15(2), 288-315.

Robertson, S. K. (2020). “Could social distancing create a long-term shift for the grocery industry?” Globe and Mail, 5 April. https://www. theglobeandmail.com/business/article-could-social-distancing-create-a-long-term-shift-for-the-grocery/

Roggeveen, A., Nordfält, J. and Grewal, D. (2013). Do digital displays enhance sales? Role of retail format and message content. Journal of Retailing 9(1), 122-131.

Shaikh, D., Chaparro, B., and Fox, D. (2006). Perception of fonts: Perceived personality traits and uses. Usability News 8(1), 1-8.

SignMedia. (2020). COVID-19 and what it means for the sign industry." SignMedia, 13 April. https://www.signmedia.ca/covid-19-andwhat-it-means-for-the-sign-industry/

Sarjakoski, T., Kettunen, P., Halkosaari, H.-M., Laakso, M., Rönneberg, M., and Stigmar, H. (2013). Landmarks and a hiking ontology to support wayfinding in a National Park during different seasons. In: Cognitive and Linguistic Aspects of Geographic Space. Lecture Notes in Geoinformation and Cartography, eds. M. Raubal, D. Mark, and A. Frank. Berlin: Springer.

Stern, N. (2020). "Four waves of change are coming to grocery retail in the wake of the Coronavirus outbreak." Forbes, 30 March. https:// www-forbes-com.cdn.ampproject.org/c/s/www.forbes.com/sites/neilstern/2020/03/30/grocery-retail-four-waves-of-changeare-coming/amp/

Sundar, A. and Kellaris, J. J. (2017). How logo colors influence shoppers' judgments of retailer ethicality: The mediating role of perceived eco-friendliness. Journal of Business Ethics 146(3), 685-701. 
Toh, M. (2020). "It's crazy: Panic buying forces stores to limit purchases of toilet paper and mask." CNN, 6 March. https://www.cnn. com/2020/03/06/business/coronavirus-global-panic-buying-toilet-paper/index.html

Tumilty, R. (2020). COVID-19: “Trudeau to Canadians: Enough is enough. go home and stay home." The National Post, 23 March. https:// nationalpost.com/news/canada / covid-19-ontario-reports-78-new-cases-the-most-in-one-day-so-far

Vizcaíno, F. V. (2018). Beyond window signs: Understanding the affect-based effects of window signs on store patronage intentions. Psychology and Marketing 35(7), 542-552.

Werner, C. M., Rhodes, M. U., and Partain, K. K. (1998). Designing effective instructional signs with schema theory: Case studies of polystyrene recycling. Environment and Behavior 30(5), 709-735.

World Health Organization. (2020). "Key considerations for repatriation and quarantine of travellers in relation to the outbreak of novel coronavirus." WHO, 11 February. https://www.who.int/news-room/articles-detail/key-considerations-for-repatriation-and-quarantine-of-travellers-in-relation-to-the-outbreak-of-novel-coronavirus-2019-ncov

World Health Organization. (2020). International Health Regulations, 2005. Geneva: WHO.

Xnage. (2020). "How much does digital signage cost? An exclusive guide." https://www.xynage.io/blog/digital-signage-cost/.

Ziliani, C., Ieva, M., Gázquez-Abad, J. C., and D’Attoma, I. (2019). Retail promotional communication: The comparative effectiveness of print versus online In: Exploring Omnichannel Retailing 2019, eds W. Piotrowicz and R. Cuthbertson. Oxford: Springer. 


\section{APPENDIX}

Table 1 / Retail Businesses Deemed Essential Based on Ontario Emergency Act by Date of Order

\begin{tabular}{|c|c|c|c|}
\hline March 24-April 2, 2020 & April 3-8, 2020 & April 9-15, 2020 & $\begin{array}{c}\text { April 16- } \\
\text { May 6, 2020 }\end{array}$ \\
\hline $\begin{array}{l}\text { Businesses engaged in retail and wholesale sale of } \\
\text { food, pet food and supplies, and household } \\
\text { consumer products necessary to maintain the } \\
\text { safety, sanitation and essential operations of } \\
\text { residences and businesses, including grocery } \\
\text { stores, supermarkets, convenience stores, markets } \\
\text { and other similar retailers }\end{array}$ & \multicolumn{3}{|c|}{$\begin{array}{l}\text { Businesses that primarily sell food, beverages and consumer } \\
\text { products necessary to maintain households and businesses } \\
\text { including supermarkets and grocery stores; convenience stores; } \\
\text { discount and big box retailers selling groceries }\end{array}$} \\
\hline $\begin{array}{l}\text { Restaurants and other food facilities that prepare } \\
\text { and serve food, but only for delivery or takeaway, } \\
\text { together with food delivery services }\end{array}$ & \multicolumn{3}{|c|}{ Restaurants (take-out, drive-through and delivery service only). } \\
\hline $\begin{array}{l}\text { Beer, wine and liquor stores and alcohol } \\
\text { producers, and stores that sell beer and wine } \\
\text { through arrangements with authorized providers, } \\
\text { cannabis stores and producers }\end{array}$ & \multicolumn{3}{|c|}{ Beer and wine and liquor stores. } \\
\hline $\begin{array}{l}\text { Motor vehicle, auto-supply, auto and motor- } \\
\text { vehicle-repair, including bicycle repair, aircraft } \\
\text { repair, heavy equipment repair, watercraft/ marine } \\
\text { craft repairs, car and truck dealerships and related } \\
\text { facilities }\end{array}$ & \multicolumn{3}{|c|}{$\begin{array}{l}\text { Vehicle and equipment repair and essential maintenance and } \\
\text { vehicle and equipment rental services. } \\
\text { Vehicle parts and supplies stores that provide products to } \\
\text { customers only through an alternative method of sale such as curb } \\
\text { side pick-up or delivery }\end{array}$} \\
\hline $\begin{array}{l}\text { Hardware stores and stores that provide hardware } \\
\text { products necessary to the essential operations of } \\
\text { residences and businesses }\end{array}$ & \multicolumn{3}{|c|}{$\begin{array}{l}\text { Hardware stores that provide products to the customer only } \\
\text { through an alternative method of sale such as curb side pick-up or } \\
\text { delivery }\end{array}$} \\
\hline $\begin{array}{l}\text { Businesses that supply office products and } \\
\text { services, including providing computer products } \\
\text { and related repair and maintenance services, for } \\
\text { people working from home and essential } \\
\text { businesses }\end{array}$ & \multicolumn{3}{|c|}{$\begin{array}{l}\text { Office supplies and computer products including computer repair } \\
\text { stores that provide products to customers only through an } \\
\text { alternative method of sale such as curb side pick-up or delivery }\end{array}$} \\
\hline $\begin{array}{l}\text { Businesses that provide essential items for health } \\
\text { and welfare of animals, including feed, animal } \\
\text { food, pet food and animal supplies }\end{array}$ & \multicolumn{3}{|c|}{$\begin{array}{l}\text { Pet and animal supplies stores that provide products to customers } \\
\text { only through an alternative method of sale such as curb side pick-up } \\
\text { or delivery }\end{array}$} \\
\hline Banks/credit unions; Insurance; Real estate agents & \multicolumn{3}{|c|}{ Banks/credit unions; Insurance; Real estate agents } \\
\hline Professional services - accountants & \multicolumn{3}{|c|}{$\begin{array}{l}\text { Financial services including payroll and payment processing and } \\
\text { accounting and tax services }\end{array}$} \\
\hline
\end{tabular}




\begin{tabular}{|l|l|}
\hline $\begin{array}{l}\text { Health care professionals providing emergency } \\
\text { care including dentists optometrists and physio- } \\
\text { therapists }\end{array}$ & $\begin{array}{l}\text { Regulated health professionals (urgent care only) including dentists, } \\
\text { optometrists, chiropractic services, ophthalmologists, physical and } \\
\text { occupational therapists and podiatrists }\end{array}$ \\
\hline $\begin{array}{l}\text { Businesses providing mailing, shipping, courier } \\
\text { and delivery services, including post office boxes; }\end{array}$ & Courier, postal, shipping, moving and delivery services \\
\hline $\begin{array}{l}\text { Gas stations, diesel, propane and heating fuel } \\
\text { providers including providers of motor vehicle, } \\
\text { aircraft and water/marine craft fuels }\end{array}$ & Gas stations and other fuel suppliers. \\
\hline $\begin{array}{l}\text { Business providing } \\
\text { pharmaceuticals/pharmaceutical services, } \\
\text { including pharmacies and dispensaries }\end{array}$ & Pharmacies \\
\hline $\begin{array}{l}\text { Businesses that sell, rent or repair } \\
\text { assistive/mobility/medical devices, aids and/or } \\
\text { supplies }\end{array}$ & $\begin{array}{l}\text { Businesses that sell, rent, or repair assistive/mobility/medical } \\
\text { devices, aids and/or supplies. }\end{array}$ \\
\hline $\begin{array}{l}\text { Laundromats, dry cleaners and laundry service } \\
\text { providers }\end{array}$ & Laundromats and drycleaners \\
\hline $\begin{array}{l}\text { Businesses providing security services including } \\
\text { private security guards; monitoring or surveillance } \\
\text { equipment and services }\end{array}$ & Security services for residences, businesses and other properties \\
\hline $\begin{array}{l}\text { Businesses that provide for health and welfare of } \\
\text { animals, including veterinarians, farms, boarding } \\
\text { kennels, stables, animal shelters, zoos, aquariums, } \\
\text { research facilities and other service providers }\end{array}$ & $\begin{array}{l}\text { Veterinary services (urgent care only) and other businesses that } \\
\text { provide for the health and welfare of animals, including farms, } \\
\text { boarding kennels, stables, animal shelters, zoos, aquariums and } \\
\text { research facilities }\end{array}$ \\
\hline
\end{tabular}

(Ontario Government 2020)

Table 2 / Timeline of Key Events, Regulations and Legislation from January to April 2020

\begin{tabular}{|c|c|c|}
\hline Month & Key Events & Regulations and Legislation \\
\hline Jan. & $\begin{array}{l}\text {-Jan 26: first presumptive case of COVID-19 recorded in Toronto, } \\
\text { Ontario, Canada } \\
\text {-Public Health Agency of Canada increases government briefings and } \\
\text { preparation }\end{array}$ & \\
\hline Feb. & $\begin{array}{l}\text {-No restrictions imposed on Canadians } \\
\text {-People continue to travel with very few restrictions (e.g. from/to } \\
\text { Hunan Province, China; Daegu and Cheongdo, South Korea) }\end{array}$ & $\begin{array}{l}\text { Feb 6: World Health Organization } \\
\text { (WHO) issues advisory that countries } \\
\text { should prepare for containment (active } \\
\text { surveillance, early detection, isolation } \\
\text { and case management, contact tracing, }\end{array}$ \\
\hline
\end{tabular}




\begin{tabular}{|c|c|c|}
\hline & & $\begin{array}{l}\text { prevention of onward spread, and data } \\
\text { sharing) }\end{array}$ \\
\hline & $\begin{array}{l}\text {-Feb 14: 7\% of Canadians concerned about contracting COVID-19 } \\
\text {-Feb 29: } 16 \text { cases reported in Canada, imported from other countries }\end{array}$ & $\begin{array}{l}\text {-Public Health Agencies begins } \\
\text { recommending that people: increase } \\
\text { hand washing; avoid touching face; } \\
\text { cough or sneeze into elbow; stay home } \\
\text { and avoid hospitals or long-term care } \\
\text { homes, if sick } \\
\text { Canadians advised to make } \\
\text { preparations should they fall ill, by } \\
\text { stockpiling food and medication for } 14 \\
\text { days }\end{array}$ \\
\hline \multirow[t]{7}{*}{ March } & $\begin{array}{l}\text {-Mar 4: Major coffee chain begin banning customer's recyclable cups, } \\
\text { and in-restaurant hard plastic and ceramic mugs }\end{array}$ & \\
\hline & & $\begin{array}{l}\text { Mar 11: WHO declares COVID-19, a } \\
\text { Pandemic }\end{array}$ \\
\hline & $\begin{array}{l}\text { Mar 13: Ontario public schools, universities and colleges ordered to } \\
\text { close }\end{array}$ & \\
\hline & $\begin{array}{l}\text { Mar 16: Some retailers ask customers to bag their own reusable bags, or } \\
\text { use plastic bags }\end{array}$ & \\
\hline & $\begin{array}{l}\text {-Reports of panic buying at grocery stores as customers worry what } \\
\text { happens if they can't get food and essential items } \\
\text {-Temporary shortages (e.g. toilet paper, cleaning supplies, water, canned } \\
\text { goods, baking supplies, fruits and longer lasting fruits and vegetables) } \\
\text {-Government encourages public not to overreact and advises that } \\
\text { Canadian supply chain has sufficient products for all, and that shelves } \\
\text { will be restocked quickly }\end{array}$ & \\
\hline & $\begin{array}{l}\text { Municipal, Provincial and Federal governments begin daily media } \\
\text { briefings }\end{array}$ & $\begin{array}{l}\text { Mar 17: Ontario government declares } \\
\text { provincial state of emergency to help } \\
\text { contain spread of COVID-19 }\end{array}$ \\
\hline & March 19: 62\% of Canadians are afraid of contracting COVID-19 & \\
\hline
\end{tabular}




\begin{tabular}{|c|c|c|}
\hline & $\begin{array}{l}\text {-Businesses, still operating at a place of business, reduce their hours of } \\
\text { operation to do extra cleaning and give employees time off } \\
\text {-Grocery stores add seniors/vulnerable population shopping hours } \\
\text {-Certain products continue to be in short supply (e.g. toilet paper, } \\
\text { cleaning supplies, canned goods, baking supplies) } \\
\text {-Some products are reserved for customer-facing employees and first } \\
\text { responders (e.g. surgical masks, hand sanitizers, isopropyl alcohol, Lysol } \\
\text { wipes, and gloves) } \\
\text {-Retailers announce a preference debit and credit cards, but most } \\
\text { continue to accept cash } \\
\text {-Restaurants/food delivery services begin to use the term 'contactless } \\
\text { delivery' (reduction in touching during food preparation; limited/no } \\
\text { interaction with customers during pick-up and delivery) } \\
\text {-Tap limits on debit and credit cards raised from } \$ 100 \text { to } \$ 250 \\
\text {-Check-out employees no longer permitted to pack customers' reusable } \\
\text { bags. Some stores waive } 5 \text { cent fee for plastic bags } \\
\text {-March } 26: \text { Some stores stop producing and/or delivering printed } \\
\text { promotional flyers }\end{array}$ & $\begin{array}{l}\text { Mar 24: First group of non-essential } \\
\text { businesses closed to employees and } \\
\text { customers (i.e. employees and } \\
\text { customers may not be in the place of } \\
\text { business) } \\
\text {-Businesses deemed essential remains } \\
\text { open to employees and customers, must } \\
\text { implement measures to ensure that } \\
\text { persons in the place of business are able } \\
\text { to maintain a separation of at least two } \\
\text { meters from others } \\
\text {-Penalties introduced to combat price } \\
\text { gouging on "necessary goods" } \\
\text {-Social distancing measures introduced } \\
\text {-Gatherings of } 50 \text { people or more } \\
\text { prohibited }\end{array}$ \\
\hline \multirow[t]{3}{*}{ April } & $\begin{array}{l}\text {-Some essential multi-locations businesses reduce the number of } \\
\text { locations open to the public } \\
\text {-Beer and wine bottle return halted } \\
\text {-Customers' reusable bags and shopping totes no longer allowed into } \\
\text { stores. Plastic shopping bags offered for free. } \\
\text {-Some stores add security guards to manage number of customers } \\
\text { entering location } \\
\text {-Seniors/vulnerable population shopping hours continue } \\
\text {-First responder priority store entry added }\end{array}$ & $\begin{array}{l}\text { Apr 4: Additional non-essential } \\
\text { businesses closed to customers. They } \\
\text { are allowed to operate with employees } \\
\text { inside store but must interact with } \\
\text { customers using alternative methods } \\
\text { such as click and collect and delivery to } \\
\text { home (hardware products; vehicle } \\
\text { supplies; pet/animal supplies; office } \\
\text { supplies, computer products; safety } \\
\text { supplies) }\end{array}$ \\
\hline & April 20: 58\% of Canadians are afraid of contracting COVID-19 & $\begin{array}{l}\text {-Fines imposed for not remaining two } \\
\text { meters apart or gathering in groups of } \\
\text { more than five people } \\
\text {-Individuals faced fines up to } \$ 5,000 \\
\text { and corporations up to } \$ 500,000 \\
\text {-More labor inspectors hired to } \\
\text { communicate COVID-19 safety } \\
\text { guidelines to essential workplaces, } \\
\text { enforce social distancing on job sites } \\
\text { and ensure non-essential businesses are } \\
\text { closed }\end{array}$ \\
\hline & $\begin{array}{l}\text { Most retailers that remained open have replaced many, but not all of the } \\
\text { informal signs with professional signs }\end{array}$ & $\begin{array}{l}\text { Apr 27: Ontario government releases its } \\
\text { "Framework for Reopening Our } \\
\text { Province" }\end{array}$ \\
\hline
\end{tabular}

